Check for updates

Cite this: RSC Adv., 2021, 11, 26444

\title{
Anaerobic digestion and agronomic applications of microalgae for its sustainable valorization
}

\begin{abstract}
Doha Elalami, (D) a Abdallah Oukarroum ${ }^{a}$ and Abdellatif Barakat (D) *ab
Microalgae are considered potential candidates in biorefinery processes, and due to their biochemical properties, they can be used in the production of biofuels such as biogas, as well as for bioremediation of liquid effluents. The objective of this review is to study the current status of microalgae anaerobic digestion and agricultural uses (as bio-stimulants and biofertilizers), starting from microalgae cultivation. Indeed, the efficiency of these processes necessarily depends on the evaluation of different biotic and abiotic factors that affect the growth of microalgae. However, the adaptation and the optimization of process parameters on a large scale is also limited by energy and economic constraints. Moreover, the integration of biogas production processes with microalgae cultivation allows a nutrients and $\mathrm{CO}_{2}$ virtuous loop, thus promoting the sustainability of the process. Finally, this paper provides a general overview of biogas and biofertilizers production combination, as well as the related challenges and recommended future research perspectives to complement the gap in the literature.
\end{abstract}

Received 22nd June 2021

Accepted 20th July 2021

DOI: $10.1039 / \mathrm{d} 1 \mathrm{ra0} 4845 \mathrm{~g}$

rsc.li/rsc-advances

harvesting stages. Biofuel production depends also on

\section{Introduction}

Microalgae are a promising source for third generation biofuels. The production of microalgae consists of cultivation and biochemical properties of microalgae which is highly related to cultivation and harvesting conditions. Light intensity, $\mathrm{pH}$, temperature and nutrients availability as well as mixing
${ }^{a}$ AgroBioSciences, Mohammed VI Polytechnic University (UM6P), Ben Guérir, Morocco.E-mail: abdellatif.barakat@inrae.fr
${ }^{b}$ IATE, University of Montpellier, INRAE, Agro Institut, Montpellier 34060, France

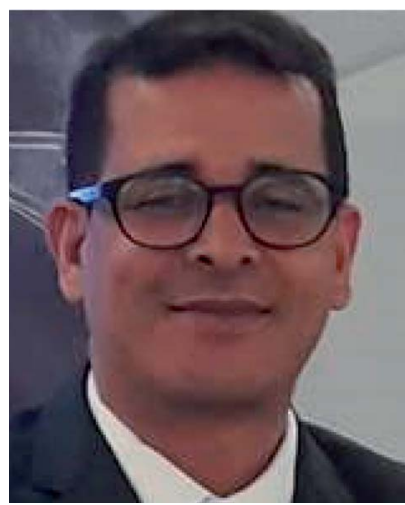

Abdallah Oukarroum is a plant physiologist with extensive experience with the study of the photosynthetic apparatus. His doctoral dissertation was conducted at the University of Geneva in Switzerland. Through his Ph.D. thesis, Abdallah Oukarroum acquired an extensive experience in study of alterations in photosynthetic apparatus of plants under environmental stress mainly drought, salt and heat stress. As well, he established two new indexes which rank plant varieties with respect to drought and heat tolerance. At University of Quebec in Montreal in Canada, Abdallah Oukarroum studied inhibitory effects and bioaccumulation of metals and metallic nanoparticles at membrane and cellular level on aquatic plants. Currently, Abdallah Oukarroum is associate professor at AgroBioSciences program. He is interested in the study of the physiological and biochemical responses to different abiotic stress of plants. 
conditions are among the main factors influencing the performance of the growth stage. ${ }^{1,2}$

Anaerobic digestion is among the most widely used biological processes converting organic matter to biogas. The efficiency of anaerobic digestion processes can be enhanced when applying a pretreatment to favor hardly degradable matter containing in microalgae. ${ }^{3}$ However, optimization of pretreatment should be carried out to reduce energy and chemicals consumption. Moreover, pretreatment cannot remedy inhibition problems related to high proteins, heavy metals or polyphenols content in microalgae, that is why co-digestion can be seen as an interesting alternative leading to high methane production. ${ }^{4}$ In addition, because of the low biomass productivity, monodigestion of microalgae cannot be economically attractive. $^{5}$

In order to improve the performance of the microalgae production and utilization system, consideration must be given to optimizing processes in such a way that the nutrient and energy loop is closed. Extraction of high-value added matter from microalgae can be carried out first to generate a biostimulant for plants for e.g., and then the solid residues can be subjected to anaerobic digestion. The resulted digestate can be used as biofertilizer or as a source of nutrients for microalgae biomass growth, ${ }^{6}$ as well as the recycling of $\mathrm{CO}_{2}$ contained in biogas produced from $\mathrm{AD}$ can lead to a more cost-effective cultivation stage.

However, more studies need to be oriented towards process life cycle assessment, in order to determine the best possible scenarios for the valorization of microalgae.

Therefore, the aim of this paper is to provide a general overview of the different aspects affecting the production and use of microalgal biomasses. In addition, this paper offers prospects for improving the valorization of microalgae residues

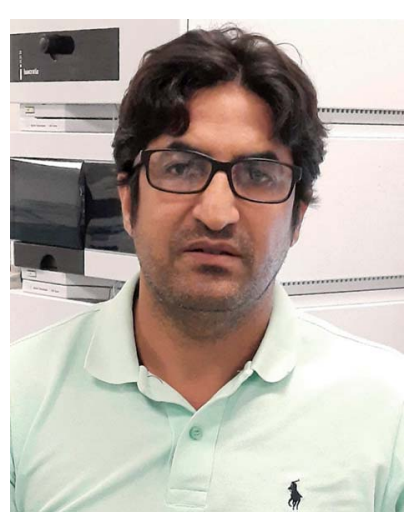

Abdellatif Barakat is a Researcher director in Bioprocess and Chemical Engineering of Biomass at INRAE in Montpellier (France), which focuses on dry fractionation and valorization of Agro-resources. He has great experiences in the field of dry fractionation, pretreatments and bioconversion of biomass and bioformulation and bioactives coating. $\mathrm{He}$ received in 2007 his $P h D$ in Chemistry and Physicochemical of biopolymers from Reims University. Before joining INRAE, he effected several Post Doc. Since 2017 Abdellatif Barakat is a head of OpenMind team at INRAE (UMR IATE). His current research interests include preparation of nanofibrils, synthesis of nanomaterials, chemical and enzymatic catalysis conversion of biomass, biochar \& microalgae production \& valorization, bioformulation \& coating, fields in which with coworkers he has published over 101 papers and 4 patents (h-index of 35). by integrating anaerobic digestion and agronomic application of microalgae in an innovative eco-friendly biorefinery in cascade.

\section{The potential of microalgae for bioenergy and biofertilization}

Microalgae are photosynthetic microorganisms that live in freshwater or seawater. They can be distinguished in two types of microalgae: eukaryotes (green or diatom microalgae) and prokaryotes (blue-green algae). Depending on the growth environment and the adaptability of the species, microalgae can grow by consuming complex organic matter (heterotrophic mode), by consuming organic matter and absorbing light (mixotrophic mode) or by absorbing only light (photoautotrophic mode).

The growth conditions as well as the type of microalgae have an impact on the properties of microalgae. Typical species include Chlamydomonas reinhardtii, Dunaliella salina, Chlorella sp., and Botryococcus braunii. Other interesting microalgae species for biotechnology development include Phaeodactylum tricornutum, Thalassiosira pseudonana, Nannochloropsis, and Isochrysis spp. ${ }^{7}$ In general, microalgae are rich in fatty acids, proteins and sugars as presented in Table 1 . In addition, some microalgal biomasses contain calcium (0.1-3\%), magnesium (0.3-0.7\%), phosphorous (0.7-1.5\%), potassium (0.7-2.4\%), sodium $(0.8-2.7 \%)$ and sulfur $(0.4-1.4 \%)$, as well as heavy metals such as copper (18-100 $\left.\mathrm{mg} \mathrm{kg}^{-1}\right)$, iron (1.4-11 $\left.\mathrm{g} \mathrm{kg}^{-1}\right)$ and zinc (28-64 $\mathrm{mg} \mathrm{kg}^{-1}$ ), as described by Tibbetts et al. (2015). ${ }^{8}$ Among the major pigments and polyphenols in microalgae there are chlorophylls $(0.5-1 \%)$, carotenoids $(0.1-0.2 \%)$, and phycobiliproteins which are present specifically in cyanobacteria. $^{9}$

Depending on the expected bio-product, the use and choice of microalgae species depends on their composition. The transformation efficiency of microalgae yield for energy, molecules and materials production are highly affected by operating conditions of the growth/harvesting and different process steps. $^{\mathbf{1 0}}$

\section{Microalgae cultivation challenges}

\subsection{Effect of operating conditions on microalgae growth}

According to Jankowska et al. (2017), the most important factors affecting microalgae growth are cultivation system, light intensity, temperature, $\mathrm{pH}$ level, $\mathrm{CO}_{2}$ concentration and nutrients availability in addition to biological factors. ${ }^{1}$

3.1.1 Light. Microalgae production is based on light provision through photosynthesis process. In fact, light intensity, the utilization efficiency as well as the radio of irradiation and dark periods are the three main factors emphasizing the impact of light on microalgae growth. ${ }^{1}$

Optimization of light intensity is required to avoid photooxidation and photoinhibition. In fact, above the light saturation point, microalgal growth is slowed down and can even be stopped, while light deficiency can lead to photo limitation, 
Table 1 Biochemical composition of some microalgal biomasses

\begin{tabular}{|c|c|c|c|c|c|c|c|}
\hline & $\begin{array}{l}\text { Carbohydrates } \\
\text { (\% TS) }\end{array}$ & $\begin{array}{l}\text { Proteins (\% } \\
\text { TS) }\end{array}$ & $\begin{array}{l}\text { Lipids (\% } \\
\text { TS) }\end{array}$ & $\mathrm{N}(\% \mathrm{TS})$ & $\mathrm{P}(\% \mathrm{TS})$ & $\mathrm{K}(\% \mathrm{TS})$ & Ref. \\
\hline Botryococcus braunii & $4-55$ & 1.5 & $25-75$ & 8.3 & 1.4 & 0.8 & 11-13 \\
\hline Chlamydomonas reinhardtii & 59.7 & 9.2 & 15-18 & - & - & - & 14 and 15 \\
\hline Chlorella sp. & $12-26$ & 53 & $28-32$ & 9.7 & 0.91 & 0.91 & 13 and 16 \\
\hline Dunaliella salina & 32 & 57 & $6-25$ & 7.0 & 0.15 & 0.43 & 16 and 17 \\
\hline Euglena gracilis & $14-18$ & $39-61$ & $4-20$ & - & - & - & 17 \\
\hline Isochrysis spp. & $4-8$ & $5-14$ & $7-40$ & - & - & - & 18 and 19 \\
\hline Nannochloropsis & 9.3 & 48.3 & $31-68$ & 7.0 & 0.7 & 1.5 & 16 and 17 \\
\hline Phaeodactylum tricornutum & 47 & 37 & $18-57$ & 8.3 & 1.2 & 2.4 & 20 \\
\hline Neochloris oleoabundans & 37.8 & 30.1 & $29-65$ & 6.3 & - & - & 8,19 and 21 \\
\hline
\end{tabular}

since, if present in excess, may cause the generation of harmful oxidative stress and reactive oxygen species (ROS). Liu et al. (2013) found that $150 \mu \mathrm{mol} \mathrm{m} \mathrm{m}^{-2} \mathrm{~s}^{-1}$ was the optimal light intensity above which microalgae growth rate was decreased. ${ }^{22}$ Patel et al. (2019) found that the increase of light intensity from 35 to $150 \mu \mathrm{mol} \mathrm{m}{ }^{-2} \mathrm{~s}^{-1}$ increased the biomass yield of Chlorella protothecoides by $124 \% .^{2}$ However, in the presence of an external source of carbon, the growth was slightly improved $(+13 \%)$ by light intensity increase. ${ }^{2}$ In the same manner, the growth rate of both Chlorella sorokiniana and Asterarcys quadricellulare doubled after the application of a light intensity of $200 \mu \mathrm{mol}$ $\mathrm{m}^{-2} \mathrm{~s}^{-1}$ compared to $50 \mu \mathrm{mol} \mathrm{m} \mathrm{m}^{-2} \mathrm{~s}^{-1} \cdot{ }^{23}$ Light intensity acts not only on growth but also on the accumulation of carbohydrates and lipids. Ho et al. (2012) reported that carbohydrates content from Scenedesmus obliquus was improved by $153 \%$ when light intensity increased from 60 to $420 \mu \mathrm{mol} \mathrm{m}{ }^{-2} \mathrm{~s}^{-1} \cdot{ }^{24}$ In another study, lipids content using Neochloris oleoabundans was increased by $26 \%$ when light intensity varied from 50 to 200 $\mu \mathrm{mol} \mathrm{m} \mathrm{m}^{-2} \mathrm{~s}^{-1} \cdot{ }^{25}$

In the case of high light intensity (greater than the light saturation point), the use of an intermittent light supply mode was recommended. In fact, the ratio of light to darkness periods is also an important parameter impacting the performance of a photo bioreactor (PBR). As explained in Patel et al. (2020), the microalgae absorb light energy under light period and fix $\mathrm{CO}_{2}$ using adenosine triphosphate (ATP) and nicotinamide adenine dinucleotide phosphate (NADPH) which have reducing powers favoring the generation of lipids within the mixotrophic cultivation system. ${ }^{26}$ Compared to continuous illumination at optimal intensity, intermittency is less effective. ${ }^{2}$ However, from an economic point of view, it reduces energy consumption.

Light absorption is also related to the distance to light source. Liu et al. (2013) reported that at biomass yield was maximal at a distance of $2 \mathrm{~cm}$ and decreased above this value. ${ }^{22}$ Therefore, the position of the energy source must be determined in such a way that the received light intensity is equal to or less than the light saturation intensity. This finding was also reported in Richmond et al. (2003), the length of optical path can highly affect the light absorbance and thus the cultivation of photoautotrophic microorganisms. ${ }^{27}$ The efficiency of light use is also related to the irradiance conditions, for example, the use of one or more light sources, placed on one side of the bioreactor or on both sides which will increase the fraction of microorganisms exposed to light at any given time. However, as high cell density can negatively affect the light penetration into the culture,${ }^{27}$ harvesting needs to be done more frequently.

3.1.2 Temperature. Temperature is another factor affecting microalgal biomass production. It is reported to be highly related to growth rate when temperature did not exceed its optimal level. However, the effect of temperature varies depending on species. In Kurpan Nogueira et al. (2015) study, increasing temperature from $20{ }^{\circ} \mathrm{C}$ to $30{ }^{\circ} \mathrm{C}$ reduced the $I$. galbana biomass yield $(-22 \%)$ while slightly enhancing lipids content $(+6 \%){ }^{28}$ This finding was not in agreement with $\mathrm{Wu}$ et al. (2013) who reported a decrease in lipid content $(-12 \%)$ when increasing temperature from 25 to $35{ }^{\circ} \mathrm{C}$ during Monoraphidium sp. growth. ${ }^{29}$

Also, when increasing temperature from 15 to $23{ }^{\circ} \mathrm{C}$, lipid content was reduced by $33 \%$, while carbohydrate content was enhanced by $43 \% .^{10}$

As seen previously, the temperature tolerance of each species can be different depending on their adaptability and gene regulation sensitivity. ${ }^{30}$ Photosynthesis is negatively affected by low temperature which reduce the carbon assimilation. However, at high temperatures, photosynthetic proteins can be degraded and cell size can be highly reduced because of the decrease in ribulose-1,5-bisphosphate activity. ${ }^{31}$

3.1.3 pH. pH can highly affect the physicochemical properties of microalgal cells. In addition, it is related to the dissolved $\mathrm{CO}_{2}$ which is the most used inorganic carbon source, and the uptake of nutrients (mainly nitrogen and phosphorous). The optimal $\mathrm{pH}$ range for microalgae growth is around 6-8. Chlorella vulgaris was reported to have a broad $\mathrm{pH}$ tolerance range up to $10 .{ }^{31}$ In contrast, Ying et al. (2014) reported the decrease in growth rate of Dunaliella salina, when $\mathrm{pH}$ drop from 7 to $6 .^{32}$ Thus, as for temperature, $\mathrm{pH}$ tolerance is specific to each species.

However, $\mathrm{pH}$ stress conditions are widely studied in literature to investigate the impact of $\mathrm{pH}$ variation on bioprocesses stability. Ho et al. (2014) reported that lipid content and quality in biomass enhanced when increasing $\mathrm{pH}$ levels, but as growth decreases, lipid productivity is reduced. ${ }^{30}$ Carbohydrates content was also found to be affected by the culture $\mathrm{pH}$. Extracellar carbohydrates content in Skeletonema costatum were 
constant in the range of 6.5-8.0 and increased above this $\mathrm{pH}$ level contrarily to growth rate. ${ }^{33}$

3.1.4 $\mathrm{CO}_{2}$ and nutrients. Carbon is a vital element for microalgae respiration and photosynthesis. It is the main part of the composition of all metabolites (lipids, carbohydrates and proteins). ${ }^{34}$ Inorganic carbon source can be taken from atmosphere in form of $\mathrm{CO}_{2}$. The concentration of $\mathrm{CO}_{2}$ plays an important role in microalgae growth. Overall, the optimal concentration of $\mathrm{CO}_{2}$ for microalgae growth is $0.038-10 \%{ }^{35} \mathrm{In}$ some cases, $\mathrm{CO}_{2}$ addition is required to avoid photorespiration, where $\mathrm{O}_{2}$ acts as Rubisco substrate which reduces $\mathrm{CO}_{2}$ fixation. ${ }^{34}$ As seen previously, $\mathrm{CO}_{2}$ tolerance depend highly on microalgae tolerance. In addition, the use of $\mathrm{CO}_{2}$ as inorganic carbon source is benefic for the ecosystem. Moreover, organic carbon can be added to stimulate lipids synthesis and biomass yield. In fact, Khanra et al. (2020) found that sucrose addition enhanced biomass yield and lipid content by $25 \%$ and $55 \%$ respectively. ${ }^{36}$ In the same manner, glucose addition was found to increase lipid productivity (4-fold higher) while reducing chlorophyll $a$ and carotenoid content. ${ }^{37}$ Moreover, depletion of carbon affects the enzyme balance and thus, alters photosynthesis. ${ }^{38}$

Nitrogen is an important nutrient, since it is essential for proteins synthesis. The three main nitrogen sources used for microalgae growth are nitrate, urea and ammonium. Khanra et al. (2020) reported that the nitrate addition as source of $\mathrm{N}$ for Chlorococcum sp. growth, enhanced biomass yield and lipid content by $40 \%$ and $117 \%$ respectively ${ }^{36}$ Similarly, Zarrinmeher et al. (2020) reported that a concentration of $72 \mathrm{mg} \mathrm{L}^{-1}$ of nitrate improved proteins $(+112 \%)$, lipids productivities $(+71 \%)$ and growth yield (15-fold high) of I. galbana compared to starvation condition..$^{39}$ Ammonium was reported to be the easiest nitrogen source to assimilate. However, growth inhibition may occur if ammonium concentration exceeds $100 \mathrm{mg} \mathrm{L}^{-1}$.40 $^{\mathrm{In}}$ mixotrophic growth conditions (with $2 \mathrm{~g} \mathrm{~L}^{-1}$ of glucose added), ammonium addition at $50 \mathrm{mg} \mathrm{L}^{-1}$ enhanced lipids and proteins content, while carbohydrates synthesis was inhibited. However, in autotrophic conditions, nitrogen reduced lipids content in microalgae. ${ }^{41}$

In the opposite side, insufficiency of nitrogen can highly improve lipid and carbohydrates content in microalgae. Under starvation conditions, microalgae degrade chlorophyll and proteins and convert its Skelton carbon to lipids and carbohydrates. ${ }^{30}$ However, biomass yield was found to be reduced in nutrient-stressed cultures compared to nutrient-replete cultures. Especially, chlorophyll $a$, nitrogen, antioxidant activity and phenolic compounds content in biomass (Chlorella, Tetraselmis and Phaeodactylum) was negatively affected by the depletion of nitrogen. ${ }^{42}$ This finding is in agreement with Ho et al. (2013) in which carbohydrates content doubled under $\mathrm{N}$ starvation of Chlorella vulgaris. ${ }^{43}$

As for nitrogen, phosphorous can highly affect biomass growth and chemical composition. It is essential for microalgae cells and nucleic acids synthesis. The most easily assimilated form of phosphorous is phosphates. Phosphorus addition at $0.04 \mathrm{~g} \mathrm{~L} \mathrm{~L}^{-1}$ didn't result in a significant change in terms of Podohedriella sp. yield. However, chlorophyll has roughly tripled and proteins content was increased by $82 \%{ }^{44}$ Phosphorous depletion was found to reduce biomass yield, $\mathrm{P}$ and chlorophyll $a$ content of the microalgae. However, vitamins $\mathrm{C}$ and $\mathrm{E}$ content in biomass was increased. ${ }^{42}$ Shashirekha et al. (2016) found that a $\mathrm{C}: \mathrm{N}: \mathrm{P}$ ratio of $0.2: 0.14: 0.8 \%$ was the optimal leading to maximized biomass $S$. obliquus yield in sugar mill effluent. ${ }^{45}$ The behavior of microalgae in the case of nutrient deficiency or sufficiency differs according to cultivation strategy, nutrients demand and the ability of microalgal species to tolerate environmental stress. Other nutrients such as trace metals are also important for microalgae cultivation as they promote enzymatic activities. Among the trace metals, iron was found to be the most important for its contribution in chlorophyll synthesis, electron transport and nitrogen fixation. ${ }^{46}$ The presence of iron with phosphorus was found to boost the production of microalgae under $0.05 \mu \mathrm{M}$ Fe and $50 \mu \mathrm{M} \mathrm{P.} .^{47}$

3.1.5 Systems configuration. Microalgae can growth using autotrophic, heterotrophic or mixotrophic modes. The autotrophic cultivation is the most common growth system. It consists in consuming inorganic carbon $\left(\mathrm{CO}_{2}\right)$ and light as source of energy. This cultivation strategy can promote pigments production, but the biomass yield can be limited compared to other growth modes. ${ }^{2,37}$ In addition, light is the limiting factor in autotrophic cultivation. In contrast, heterotrophic mode is defined by the use of organic carbon instead of inorganic one as source of carbon and energy. Thus, light is not required for this type of systems. The growth rate and biomass productivity were shown to be high using heterotrophic cultivation. However, not all of microalgae species can be grown in these conditions. Amphora, Ankistrodesmus, Chlamydomonas, Chlorella, Chlorococcum, Crypthecodinium, Cyclotella, Dunaliella, Euglena, Nannochloropsis, Nitzschia, Ochromonas, and Tetraselmis were found to be able to grow heterotrophically ${ }^{48}$ Moreover, contamination by other microorganisms can occur which may reduce microalgae productivity. Microalgae can use both organic carbon for respiration, inorganic carbon and light for photosynthesis, which is known as mixotrophic growth. Spirulina platensis, Chlamydomonas reinhardtii, Chlorella sorokiniana, Scenedesmus obliquus, and C. vulgaris are among the most known microalgae species that can grow under mixotrophic conditions. ${ }^{49}$ This system favors metabolites production while gathering advantages of both autotrophy and heterotrophy. ${ }^{37,49}$

Microalgae cultivation can be carried out in open ponds or closed photobioreactors. Photobioreactors are using light source for phototrophic microorganisms' growth. In this system, environmental factors are easy to control. Operating conditions may affect $\mathrm{CO}_{2}$ (then $\mathrm{pH}$ ), nutrients, heat transfer and light availability in the cultivation system. ${ }^{1}$ Thus, mixing is among the most important parameters related to reactors functioning. Maximizing mixing condition favors biomass growth, as long as shear stress is taken into account, which is related to the culture medium velocity. ${ }^{1,35}$ As previously mentioned, light path can also affect microalgae growth. For photobioreactors, construction materials can play an important role in light absorption. ${ }^{48}$ Light attenuation should also be 
controlled by modifying the residence time to avoid dark zones within the PBR and then a decrease in biomass productivity. ${ }^{\mathbf{5 0}}$

Also, an optimized diameter should be considered to accommodate the uniform distribution of light within the reactor. ${ }^{51}$ The modelling of PBR systems has already been reported in the literature ${ }^{50,52}$ but has not been addressed in this review.

The raceway pond is the cheapest cultivation system with a cost investment of 0.13 to $0.37 \mathrm{M} €$ per ha. ${ }^{53}$ It consists in an oval channel containing a paddle wheel to ensure the continuous water flow. It used sunlight for microalgae growth what makes the strength of this technique.

The most appropriate design of raceway ponds should enhance the productivity and thus, limiting the photoinihibition and photolimitation. These latter are generally avoided by optimizing the water head and reducing pond depth, which favors the contact of microalgae with light. In addition, low water head can be operated by a propeller which consumes less energy compared to paddle wheels. ${ }^{54}$

The use of existing wastewater lagoons for microalgae cultivation was found to be the most profitable way to produce biomass at large scale. ${ }^{55}$ In addition, nutrient supply, water and sunlight are provided. Utilization of photobioreactors is generally more productive, but some constraints related to reactor sizing should be considered. Norsker et al. (2020) reported that the maximal recommended length of tubular photobioreactor with diameters between $5-10 \mathrm{~cm}$ is around $80-120$ $\mathrm{m}$. The dimensions of the photobioreactors depend mainly on dissolved oxygen tolerance and flow velocity. Larger diameters were found to result in lower biomass concentration and density and lower diameters are uneconomical in terms of mixing energy because of shear stress. ${ }^{48}$ In contrast, open raceway ponds are the most frequently used systems at industrial scale due to their cost effectiveness. It can extend from 1000 to $5000 \mathrm{~m}^{2},{ }^{53}$ for which the maximal depth is $0.45 \mathrm{~m} \cdot{ }^{56}$ However, contamination issues, harvesting difficulty and environmental conditions changes may be the challenges encountered by this type of systems.

When using open ponds, environmental changes including, temperature and humidity, can affect the productivity of biomass. In addition, loss of water through evaporation can occur. ${ }^{56}$ The use of sunlight can highly reduce the costs of microalgae production. However, this abundant energy source is not fixed and cannot be controlled. The variability of its intensity can lead to an unreliability of the process and therefore to a non-optimized production of microalgae, especially in cases where the objective is to produce products with high added value. ${ }^{57}$ For heterotrophic cultivation, the use of organic carbon source such as glucose, can lead to extra costs.

\subsection{Biological contamination issues}

Biological contaminants affecting the growth of microalgae are classified into 4 categories: zooplankton, microorganisms (bacteria, fungi and protozoa), other microalgae species and viruses. ${ }^{58}$ Contaminants can also be distinguished according to their contamination mechanisms. Microalgae grazers are found in all-natural aquatic environments. They present the greatest threat on microalgae growth. By ingesting microalgae, they cause reduction of biomass production. Park et al. (2016) reported that Chlorella kessleri can be highly infected by rotifers such as Brachionus calyciflorus. The solution given in the study suggests that addition of chlorine can help preventing pond crash. ${ }^{59}$ Also, the capacity of Brachionus calyciflorus to consume more than 500 cells of Chlamydomonas reinhardtii per hour and per rotifer was reported. ${ }^{58}$

Grazers prevention can be carried out by sterilizing the medium before introduction in photobioreactors. ${ }^{60}$ However, the risk of contamination is high in open ponds compared to photobioreactors. In case of open ponds, the use of greenhouses has shown a positive effect on the reduction of the risk of wind infection by cysts and grazers eggs that are threatening microalgae. ${ }^{60}$ Other chemical treatments such as pesticides were studied, but their cost and impact on environment shows that their application in a larger scale may be inefficient. Moreover, the increase of $\mathrm{CO}_{2}$ concentration was found to be effective in controlling and eliminating grazers. ${ }^{61}$

In literature, the use of algal-bacterial co-culture based on crashed rotifer culture, had a positive impact on protecting Microchloropsis salina against Brachionus plicatilis. After months of repeating the assays, the algal-bacterial co-culture was no longer effective in protecting microalgae grown in open ponds. This was due to the absence of certain genus in the nonprotective community. However, studies need to be carried out to ensure the reliability of this practice. ${ }^{62}$

\section{Biogas production from microalgae}

Anaerobic digestion (AD) is the biological process converting organic methane to biogas which is composed mainly of methane and $\mathrm{CO}_{2}$ (Fig. 1). As microalgae is rich in organic matter, its anaerobic digestion had attracted researchers' interest since 1982. Considering that, $1 \mathrm{~g}$ of carbohydrates, proteins and lipids produce 415, 496 and $1014 \mathrm{~mL}$ of methane. Thus, theoretically, Chlorella sp. can produce around $600 \mathrm{~mL}$ of

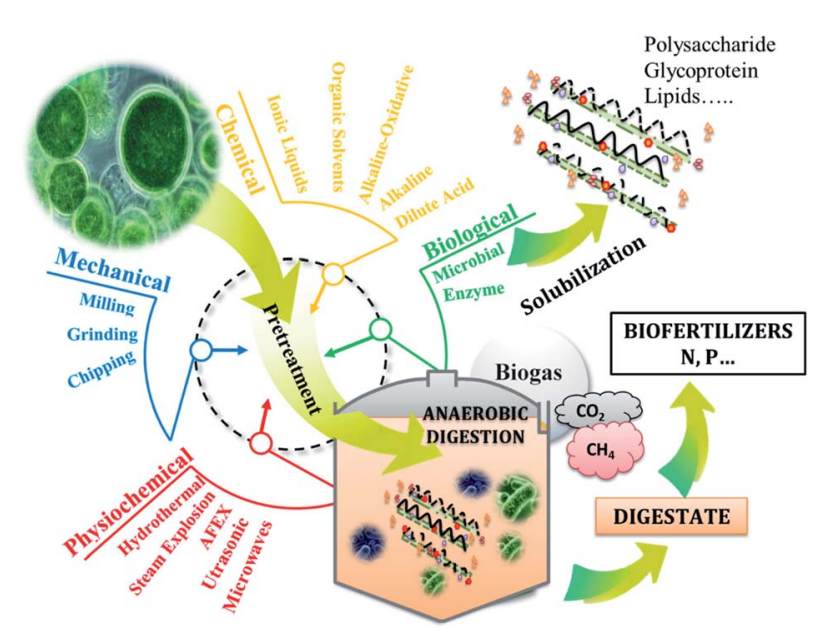

Fig. 1 Pretreatments and biogas production from microalgae. 
methane per gTS. Mussgnug et al. (2010) found that the methane potentials of Chlamydomonas reinhardtii, Chlorella, Dunaliella salina and Euglena gracilis were 587, 335, 505 and $485 \mathrm{~mL} \mathrm{~g}^{-1}$ VS respectively. ${ }^{63}$ Other algal biomasses such as Isochrysis sp. had lower methane potential (135 $\left.\mathrm{mL} \mathrm{g}^{-1} \mathrm{VS}\right)$ compared to the others, ${ }^{64}$ as long as it contained low carbohydrates (4-8\%TS) as shown in Table 1.

Anaerobic digestion process is the succession of 4 stages: hydrolysis, acidogenesis, acetogenesis, and methanogenesis. In which the complex organic matter is broken down by the microorganisms into monomers, then volatile fatty acids, then into acetate, hydrogen and $\mathrm{CO}_{2}$, ultimately leading to the production of methane. ${ }^{65}$ The recalcitrance of microalgal cell walls can be the reason behind the low methane production. ${ }^{66}$ Thus, pretreatments may be needed to increase solubilization of organic compounds contained in microalgae biomass and therefore, enhance the hydrolysis yield. The latter can be considered as the limiting step of $\mathrm{AD}$ process in the case of hardly biodegradable matter.

Many factors can affect the $\mathrm{AD}$ process, such as temperature (mesophilic or thermophilic), $\mathrm{pH}$ (6.5-7.5), $\mathrm{C}$ to $\mathrm{N}$ ratio (20-25) and operating conditions (organic loading rate, hydraulic retention time and mixing conditions). In the case of microalgae, Zamalloa et al. (2012) reported that thermophilic AD $\left(54{ }^{\circ} \mathrm{C}\right)$ resulted in lower methane production from Scenedesmus obliquus and Phaeodactylum tricornutum compared to mesophilic temperature $\left(33^{\circ} \mathrm{C}\right) \cdot{ }^{67} \mathrm{C}$ to $\mathrm{N}$ ratio in Chlorella vulgaris was found to be around $17,{ }^{68}$ while Stigonematales sp had lower $\mathrm{C}$ to $\mathrm{N}$ ratio (around 4.7). ${ }^{69}$ This suggests that digestion of microalgae with other organic substrates with higher $\mathrm{C}$ to $\mathrm{N}$ ratio can be carried out to enhance biogas production, which is known as codigestion. By its simplicity and low energy and chemicals requirements, $\mathrm{AD}$ can be an efficient bioprocess for microalgae transformation into bioenergy. When $\mathrm{AD}$ of microalgae is applied as downstream process, steps such as dewatering and drying of microalgae are not required. In the case of an existing digester within the wastewater treatment plant, the co-digestion of microalgae with sewage sludge can be feasible and profitable. ${ }^{70}$

\subsection{Pretreatment of microalgae}

Pretreatment is a well-known practice in microalgae valorization such as anaerobic digestion (Fig. 1). Hence, the pretreatment of microalgae prior to its valorization is an essential step in order to increase macromolecules accessibility and biodegradability by anaerobic microorganisms. Application of pretreatment steps allows modifying the supramolecular structure of microalgae matrix, thereby changing the natural binding characteristics of microalgae materials and increasing the carbohydrates, proteins, lipids... accessibility for enzymatic or chemical biological action. For the last few years, several physicochemical pretreatments have been developed and applied to microalgae biomass for this purpose, including ultrasonic, mechanical, microwaves, chemical, biological, thermal and combined pretreatments. However, although most of them are known to be effective in hydrolysing the matrix and enhance sugars recovery, they are energy consuming and not always cost effective. ${ }^{71}$ Microalgae biomass cell is composed of the skelton containing cellulose, mannan and xylans. ${ }^{3}$ In addition, cell walls are composed of polysaccharide and glycoprotein matrix protecting microalgal cells. ${ }^{72}$ However, the composition of cell walls varies from species to species. Dunaliella sp. has no cell wall while Chlorella and Scenedesmus sp. can further contain algeanan which is a lignin-like polymer. ${ }^{3,73}$ The robustness of this wall obviously depends on the growing conditions, such as the attack of the grazers or variable environmental conditions. ${ }^{74}$ For this reason, the key driver for the successful conversion of microalgae into energy and high values added compounds is the selection of efficient pretreatments that permit to maximize the sugars, lipids and proteins recovery and to minimize their degradation with the consequent formation of toxic derivatives. Thus, the $\mathrm{AD}$ of microalgae may require pretreatments of which some recent results are summarized in Table 2.

Thermal pretreatment of Chlorella vulgaris at $120{ }^{\circ} \mathrm{C}$ for 40 min improved organic matter solubilization leading to an enhanced methane production by $93 \% .{ }^{75}$ In the same manner, subjecting Nannochloropsis salina to $120{ }^{\circ} \mathrm{C}$ for $2 \mathrm{~h}$ resulted in $150 \%$ more biogas produced. ${ }^{76}$ However, according to Mussgnug et al. (2010), thermal pretreatment at $105{ }^{\circ} \mathrm{C}$ for $24 \mathrm{~h}$ can lead to reduced biogas production by $18 \%$, which may be due to volatilization of organic matter. ${ }^{63}$ Applying microwaves to a coculture of Chlorella and Scenedesmus sp. can result in high solubilization of VS with a $13 \%$ higher methane production. ${ }^{77}$ However, Schwede et al. (2013) reported that microwaves can lead to higher methane production (+40\%) from Nannochloropsis salina. Microwaves are generally used to substitute conventional heating that consume more energy and take more time. However, the effectiveness of conventional heating can be higher than that of microwaves as reported in Schwede et al. (2013). In this case, it is necessary to consider whether the energy dissipated by the conventional heat pretreatment is compensated by the increase in methane production. Ultrasonic pretreatment is generally used to disrupt flocs and when applied to microalgae, it was found to improve solubilization of VS, but negative or low effect on methane production was reported. ${ }^{78,79}$ Acid and alkaline pretreatments were also studied and a methane production increase by 15 and $16 \%$ were respectively found. ${ }^{64,70}$ However, by combining thermal and chemical pretreatments, methane production can be enhanced as found in a previous work. ${ }^{75}$ Moreover, biological pretreatment can achieve high methane production increase. It is the most eco-friendly pretreatment since it is generally carried out at mild conditions. Ciudad et al. (2014) found that fungi pretreatment enhanced methane production of botryococcus braunii by $67 \%,{ }^{80}$ while an increase of $87 \%$ of methane production was reported after the biological pretreatment of chlorella vulgaris. ${ }^{81}$ Methane production from Scenedesmus sp. was also increased by $68 \%$ after enzymatic pretreatment. ${ }^{82}$ The efficiency of pretreatment depends highly on the methane production increase, costs related to energy and chemical consumption as well as the impact of pretreatment on digestate management. 
Table 2 Effect of microalgae pretreatments on its anaerobic digestion

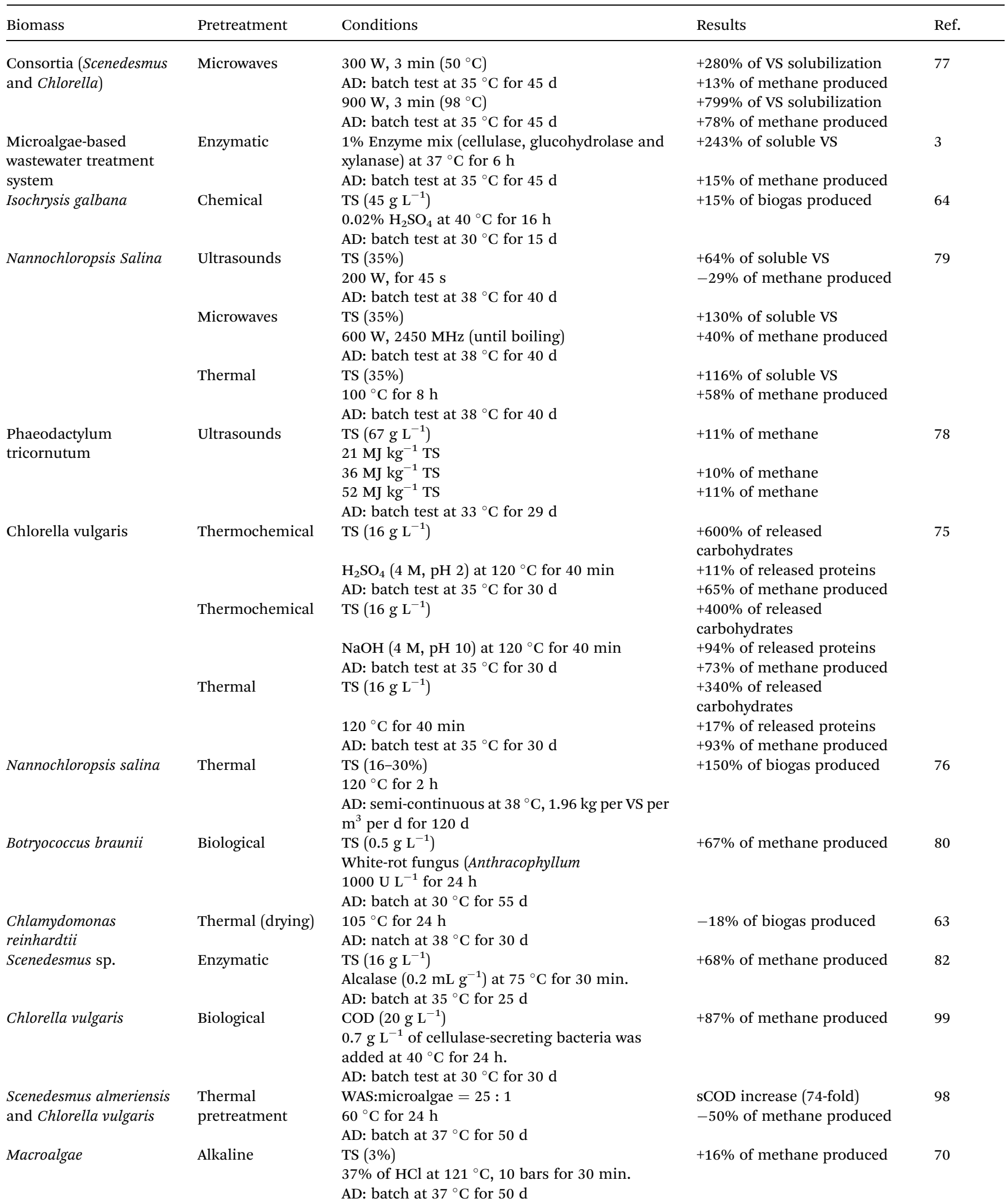




\subsection{Codigestion of microalgae}

As mentioned previously, codigestion aims to adjusting $\mathrm{C}$ to $\mathrm{N}$ ratio, humidity and diluting inhibitory compounds such as polyphenols. ${ }^{83}$ Thus, codigestion of microalgae can improve methane production depending on methane potential of the cosubstrate. Codigestion of microalgae with sludge was much studied. Microalgae can be used in WWTPs to treat wastewater effluents ( $\mathrm{N}$ and $\mathrm{P}$ removal), their co-digestion with sludge in already existing digester in WWTPs appears to be an effective and cheaper way to valorize them. Many studies have investigated the effect of different microalgae to sludge ratio on methane production synergism. However, on a real scale, this ratio cannot exceed $50 \%$. It is generally between $5 / 95$ and 20/80 (based on VS). ${ }^{4}$ In order to achieve the optimal $\mathrm{C}$ to $\mathrm{N}$ ratio of microalgae and septic sludge mixture, algal proportion should be within the range of $25-75 \%$ and a 3 -fold improved methane production was observed compared to microalgae monodigestion. ${ }^{84}$ Similarly, Wang et al. (2013) reported that Chlorella sp. ratios of $4 \%$ and $11 \%$ resulted in enhanced methane production compared to microalgae alone $(73-79 \%) .{ }^{85}$ The synergetic effect of sludge and Chlorella sp. codigestion is not always observed, which was the case in. ${ }^{86}$ Codigestion of sludge with $4 \%$ of Chlorella sp. resulted in higher dewaterability of digestate compared to monodigestion of microalgae. In addition, it was richer in ammonium and phosphorus, which suggests that its agronomic quality was improved due to sludge addition. ${ }^{85}$ In parallel, addition of microalgae to sludge AD can highly affect digestate composition. Solé-Bundo et al. (2019) found that caffeine and triphenyl phosphate were removed from codigestion effluent by $92 \%$ and $64 \%{ }^{87}$ Other organic wastes such as agricultural residues, animal wastes and food waste were studied as co-substrates of microalgae digestion. Agricultural residues are known for having a relatively high $\mathrm{C}$ to $\mathrm{N}$ ratio. ${ }^{\mathbf{8}}$ Thus, their codigestion with microalgae can improve the methane production. Potato peels wastes codigested with Chlorella vulgaris at a ratio of 25/75 resulted in $32 \%$ higher methane production, ${ }^{89}$ where the $\mathrm{C}$ to $\mathrm{N}$ ratio increased when increasing potato peels proportion. Wheat straw was also used as cosubstrate for microalgae biomass containing mainly Chlorella sp. at a ratio of 50/50 (VS basis), AD was found to be slightly synergetic with $7 \%$ of additional methane production. ${ }^{\mathbf{9 0}}$ Moreover, codigestion of Microcystis spp. with corn straw was studied to enhance $\mathrm{C}$ to $\mathrm{N}$ ratio. It was shown that at a $\mathrm{C}$ to $\mathrm{N}$ ratio of $20 / 1$, methane production was maximal with an increase of $62 \%$ compared to microalgae monodigestion. ${ }^{91}$ Passos et al. (2018) reported that codigestion of Chlorella sp. with coffee husks provided $17 \%$ more methane production compared to theoretical production determined based on methane potential of both substrates. ${ }^{92}$ However, in the literature, many studies are focused on certain species such as Chlorella sp. It is assumed that other microalgal biomasses, especially those rich in proteins such as Dunaliella salina and Euglena gracilis, should be studied in codigestion with carbonrich organic substrates to adjust their $\mathrm{C} / \mathrm{N}$ ratio, and avoid inhibition by ammonia. ${ }^{93}$ Recently, codigestion of Dunaliella salina and olive mill solid waste was studied at a ratio of 5/95 and resulted in $29 \%$ high methane production compared to olive mill solid waste alone. ${ }^{94}$ When mixing Scenedesmus sp. with pig manure at a ratio of $1 / 1$, methane production was enhanced by $50 \%$ compared to microalgae alone, however, no synergetic effect was observed. ${ }^{95}$ Food waste is also a carbon rich material, that is widely used as cosubstrate of sludge. It was already studied in codigestion with a mixture of Chlorella vulgaris and Scenedesmus obliquus. Results showed that at a ratio of $12 / 88$ (microalgae to food waste ratio), methane production was enhanced by $20 \%$ compared to monodigestion of food waste. ${ }^{96}$

Anaerobic digestion can be integrated to microalgae valorization processes, such as lipid extraction and biodiesel production. In fact, microalgae residues from biodiesel production can be digested alone or codigested with other organic wastes. Relatively low synergy of methane production was obtained after the codigestion of lipid spend microalgae and glycerol at a ratio of 67/3. This was explained by the low $\mathrm{C}$ to $\mathrm{N}$ ratio of the mixture and also the potential inhibitory impact of the used solvent for transesterification. ${ }^{97}$ Lipid extraction can be seen as a pretreatment step, as it can enhance biomass accessibility improving, thus, its methane potential, which was reported in..$^{95}$ Moreover, codigestion of lipid extracted microalgae with pig manure had the same effect as raw microalgae codigestion with pig manure at similar mixture ratio, ${ }^{95}$ which raises the question of the effectiveness of combining co-digestion and molecules extraction of microalgae.

\subsection{Combining codigestion and pretreatment}

Theoretically, the hard digestibility of microalgae and some organic wastes can reduce the benefit of their codigestion. Thus, pretreatments can be carried out to one substrate or to the mixture. In fact, Mahdy et al. (2015) reported that thermal pretreatment at $120{ }^{\circ} \mathrm{C}$ for 40 min of Chlorella vulgaris before its mixture with primary sludge, improved methane production by $10 \%{ }^{82}$ Similarly, pretreated microalgae mixed with sludge and fats, oil and grease resulted in $15 \%$ higher methane production compared to untreated microalgae. ${ }^{86}$ However, the authors do not recommend the pretreatment as it has generally negative energy balance which must be compensated by a greater improvement in methane. Thermal hydrolysis $\left(120^{\circ} \mathrm{C}\right.$ for $\left.60^{\circ} \mathrm{C}\right)$ of the mixture of microalgae and coffee husks increased methane production by $15 \%$. However, it is assumed that the impact of pretreatment on individual substrates was more important (18\% and $31 \%$ for microalgae and coffee husks respectively). ${ }^{92}$ In some cases, the effect of pre-treatment is reversed. In fact, when low temperature pretreatment $\left(60{ }^{\circ} \mathrm{C}\right.$ for $24 \mathrm{~h}$ ) was applied to microalgae and sludge mixture at a ratio of $1 / 25$, methane production was reduced by $51 \%$ compared to untreated mixture. ${ }^{98}$ However, previous researches assumed that there is no need to pretreat microalgae prior its codigestion. Moreover, additional costs related to chemicals and energy consumption can be generated.

\section{Microalgae for agriculture}

\subsection{Impact on soil properties}

Fig. 2 illustrates the different agronomic applications of microalgae. Soil degradation can be trigged by the extensive 
agricultural practices in the fields which may affect $30 \%$ of the cultivable soils. ${ }^{\mathbf{1 0 0}}$ The application of microalgae enhances soil organic matter through production of exopolysaccharides which favors the growth of soil's fauna and flora. In addition, the inoculation of microalgae promotes the solubilization and mineralization of nutrients due to its photosynthetic activity. ${ }^{\mathbf{1 0 1}}$ Yilmaz and Sönmez (2017) found that the use of Chlorella vulgaris as biofertilizer added to vermicompost increased the soil aggregates stability and organic carbon by $19 \% .{ }^{102}$ Table 3 presents the effect of some microalgae use as fertilizer on soil nutrients. Chlorella vulgaris and Scenedesmus quadricauda were previously used as biofertilizers. It was found that the enzymatic activity of soil was enhanced by the addition of living microalgae as well as their extracts. ${ }^{103}$ However, the use of live microalgae allows the in situ growth of these microorganisms at soil level, without the need for a separate cultivation process. ${ }^{104}$ In addition, this technique reduces the costs related to the extraction of biostimulants or the drying of the algal biomass. Moreover, combining cyanobacteria with microalgae resulted in increased desert soil stability. ${ }^{105}$ In the same manner, the application of microalgal consortia was found to enrich soil with the essential nutrients $(\mathrm{N}$, $\mathrm{P}$ and $\mathrm{K}){ }^{106}$ However, compared to cyanobacterial consortia, Chlorella application was less effective in enriching soil with nutrients. ${ }^{106}$ Moreover, Dineshkumar et al. (2018) found that nitrogen, phosphorous and potassium and soil enzymes activities were positively affected by the use of Chlorella and $S$. platensis as biofertilizers, but the impact of $S$. platensis was the highest. ${ }^{107}$ In addition, the use of microalgae and cyanobacteria was found to reduce the required $\mathrm{N}$ fertilizer dose. ${ }^{107}$ Other essential nutrient such as iron, magnesium and zinc were found to be positively affected by microalgae and cyanobacteria addition. ${ }^{\mathbf{1 0 8}}$ Moreover, algal biomass can generate siderophores which promote ferric iron chelation and thus make it more accessible to plants and soil' microbial communities. ${ }^{\mathbf{1 0 1}}$

Microalgae can promote the formation of biological soil crusts which help maintaining soil's biota and thus fertility. Yet, the greatest interest in using living microalgae in soils arises in their application to degraded soils such as desert soil. In fact, microalgae can be associated with minerals to form water-stable organomineral formulation which enhance arid soil fertility. ${ }^{109}$ In addition, microalgae can survive the severe conditions due to their cellular structure especially the presence of cysts. For instance, Protosiphon botryoides, was reported to survive and was still active after 43 years in a dried soil content. ${ }^{\mathbf{1 1 0}}$ In the same context, Perera et al. (2018) highlighted the benefit of using the engineered consortia of cyanobacteria/microalgae for rehabilitating desert ecosystems. ${ }^{\mathbf{1 0 5}}$ However, the agronomic potential of microalgae may be limited by their growth which may be affected by soil moisture, $\mathrm{pH}$ (which need to be slightly acidic to basic) and temperature. ${ }^{\mathbf{1 0 0}}$ More studies should be carried out to investigate the mechanisms of soil fertilization by microalgae, especially in arid environments.

\subsection{Impact on plant growth and properties}

As seen previously, microalgae application can affect soil properties and thus increase availability of nutrients to the plants. In addition, it provides assimilable nitrogen to plant through atmospheric nitrogen fixation. ${ }^{111}$ As the first step of plant growth is germination, healthy seedlings can be obtained due to microalgae application. ${ }^{103}$ Some literature results showing the impact of microalgae and cyanobacteria on plant growth, are given in Table 3. Uysal et al. (2015) investigated the impact of Chlorella sp. in wheat and maize germination. It was found that an enhancement of $17 \%$ and $40 \%$ of germination rate was noticed for wheat and maize respectively. ${ }^{\mathbf{1 1 2}}$ Moreover, germination rate of bell pepper was increased by $36 \%$ after the application of both Dunaliella salina and Phaeodactylum tricornutum. ${ }^{113}$

Chlorella vulgaris and Spirulina platensis were found to enhance dry weight of maize plant by $30 \%$ and $35 \%$ which was increased to achieve $38 \%$ and $49 \%$ when adding a chemical fertilizer. ${ }^{114}$ Wuang et al. (2016) found that Spirulina platensis enhanced dry weight of red spinach plant and its chlorophyll content and when mixed with chemical fertilizer, the application efficiency was enhanced. ${ }^{115}$ Similarly, microalgae was reported to have higher impact on plant weight and pigments compared to inorganic fertilizer. ${ }^{\mathbf{1 1 6}}$ However, Jimenez et al. (2020) found that microalgae enhanced tomato plant weight and chlorophyll $a$ by $32 \%$ and 13\% compared to unfertilized soil, while industrial fertilizer had similar effect on tomato plant weight but higher impact on chlorophyll $a$ ( $+69 \%$ with respect to control). ${ }^{117}$ Also, it was reported that microalgae use had significant impact on nitrogen leaching (7\% of loss) compared to industrial fertilizer (50\% of loss). ${ }^{117}$

In fact, during their growth, microalgae uptake macro and micro nutrients and store them in their cells, ${ }^{111}$ which explains their potential compared to chemical fertilizer. This effect depends strongly on species and their growth conditions, ${ }^{\mathbf{1 0 3}}$ dosages $^{118}$ and crop plant. ${ }^{112}$ An algal liquid fertilizer was obtained using $500 \mathrm{mg}$ of dried Chorococcum sp. biomass in $200 \mathrm{~mL}$ of distilled water. This algal liquid was found to have the best effect on 4 plants growth with a concentration of $50 \% .{ }^{118}$

Moreover, the use of fresh or dried biomass was reported to have different impacts on lettuce growth in which case, fresh microalgae was recommended. ${ }^{119}$ The enhancement of plant growth after microalgae/cyanobacteria inoculation is owed to their metabolites, which are capable of initiating plant metabolic reactions, such as respiration, photosynthesis, nucleic acid synthesis, chlorophyll production and ion absorption. ${ }^{\mathbf{1 2 0}}$ This finding was in agreement with Dineshkumar et al. (2019), in which cyanobacteria and microalgae mixtures with cow dung enhanced pigments and nitrogen, potassium and phosphorus contents in the maize plants. ${ }^{\mathbf{1 1 4}}$

However, another study has shown that elemental composition of tomato plants were not significantly affected by microalgae addition as fertilizer, while nitrogen content was slightly increased due to industrial fertilizer incorporation. ${ }^{\mathbf{1 1 7}}$ The results of using microalgae in soil fertilisation differ according to the cultivation and agronomic tests conditions. However, the interest in using these species as biofertilisers remains high. More research studies are needed to understand much better the different interactions between these species 

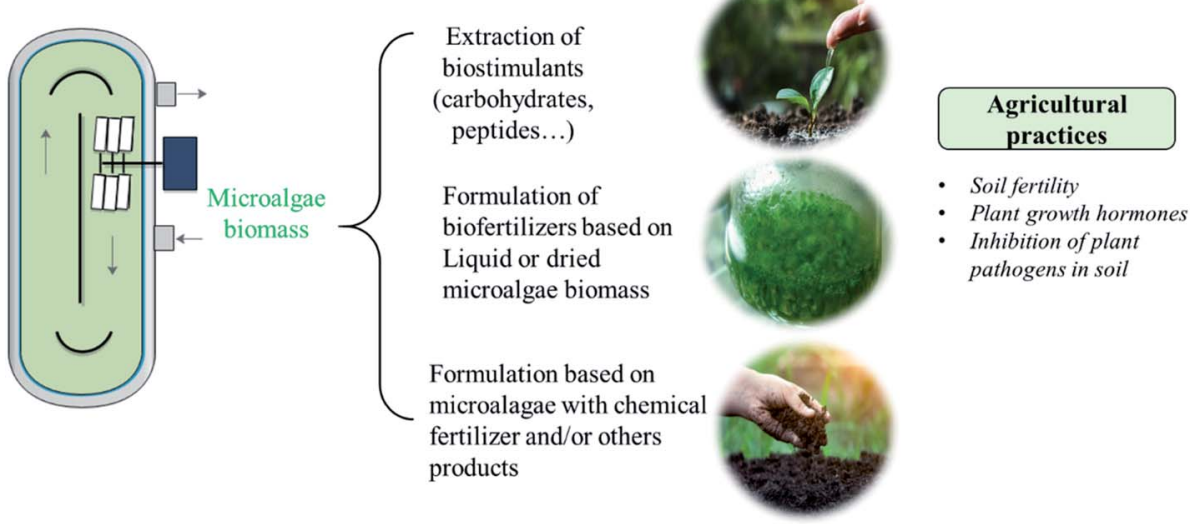

Fig. 2 Microalgae uses in agriculture.

and the soil/plant and the impact of biofertilisation on the nutritional quality of the fruit of these plants.

Despite the positive impact of applying microalgae biomass and extracts as fertilizer, the optimization of its concentration should be considered in order to maximize its advantage for plant growth. A $60 \%$ concentration of microalgae led to higher length, dry weight and chlorophyll content in tomato plant. ${ }^{121}$

Without any regard to the effectiveness of microalgae application, the use of microalgae as biofertilizer was found to be less beneficial compared to NPK fertilizer, which is mainly caused by microalgae cultivation and harvesting processes. ${ }^{124} \mathrm{In}$ the absence of optimization of these processes, the use of algae in agronomy may be less economically and environmentally attractive. In addition, the abiotic factors related to the growth environment can highly affect both the productivity and the biochemical composition of the microalgae.

To improve the profitability of the conversion of microalgae into valuable products for agronomy, the selection of microalgae strain to be used should be done in the basis of its composition and growth conditions. In addition, depending on extraction methods, several biofertilizers and biostimulants formulations can be realized.

For the commercialization of microalgae products, it is recommended to adopt a quality management system and the standardization of microalgae production processes to control the efficiency of the produced microalgae-based fertilizers. ${ }^{125}$ Good field practices of these biofertilizers must be established, also the choice of plants and the frequency of treatment play a role in the effectiveness of these products. ${ }^{124}$

\section{Closed-loop valorization of microalgae}

\subsection{Microalgae digestate as fertilizer}

Generally, the composition of digestate depends on substrate composition, inoculum sources, $\mathrm{AD}$ conditions and configurations. Table 4 presents some typical properties of digestate. Digestate can be used as an organo-mineral fertilizer substituting the mineral fertilizers, due to its macronutrients elements (nitrogen, phosphorous and potassium). ${ }^{126}$ In addition, digestate is often rich in metal trace elements that are essential for plant germination and growth. However, an excessive heavy metal concentration or salinity can limit the use of digestate as fertilizer or amender. According to EU regulations, the limit concentrations of biosolids to be applied to soil should not exceed 2, 1000, 800, 10, 200, 1000 and $3000 \mathrm{mg} \mathrm{kg}^{-1}$ $\mathrm{TS}$ for $\mathrm{Cd}, \mathrm{Cu}, \mathrm{Pb}, \mathrm{Hg}, \mathrm{Ni}, \mathrm{Cr}$ and $\mathrm{Zn}$ respectively. Moreover, digestate is much cheaper than mineral fertilizer, with a cost saving of $390 €$ per ha. ${ }^{127}$

Microalgae digestate can be used as biofertilizer as it is rich in organic matter, nutrients and heavy metals as presented in Table 4. Microalgae digestates was found to meet the European material requirements for an organic amendment. Available forms of nutrients in liquid and solid fractions of digestate from lipid-extracted C. muelleri were reported in a previous study. ${ }^{131}$ In fact, $55 \%$ of nitrogen was found in solid digestate while $68 \%$ of phosphorus was released in liquid fraction. Phosphorus was found to be more available in algal digestates compared to dairy manure. ${ }^{132}$ Even if the nitrogen was immobilized in the solid fraction, ammonium content in the dissolved organic matter fraction accounted for $40 \%$, which highlights the fertilizing potential of microalgae digestate. ${ }^{131}$

Moreover, most Oocystis sp. cells were not degraded in digestate. This suggests that: (i) hydrothermal pre-treatment $\left(130{ }^{\circ} \mathrm{C}\right.$ for $\left.15 \mathrm{~min}\right)$ improves the degradation of the organic matter contained in the microalgae and thus its methanogenic potential and also, (ii) to preserve organic matter for soil amendment with microalgae digestate, pre-treatments will not be favorable. ${ }^{133}$ In addition, the presence of living microalgae can promote soil biofertilization. This finding was also reported in another study, where Stigeoclonium sp., diatoms Nitzschia sp. and Amphora sp. were present in digestate. The microalgal cells degradation during anaerobic digestion depend highly on algal stains. ${ }^{134}$

In addition, Solé-Bundo et al. (2017) study showed that microalgae digestate increased the growth index of cress by $10 \%$ which was lower than the growth index after codigestion residue application ( $75 \%$ VS of sludge and $25 \%$ VS of microalgae). Despite its lower nutrient content compared to monodigestate, the codigestion residue was found to present less phytotoxicity 
Table 3 Effect of microalgae/cyanobacteria application for soil fertilization in literature

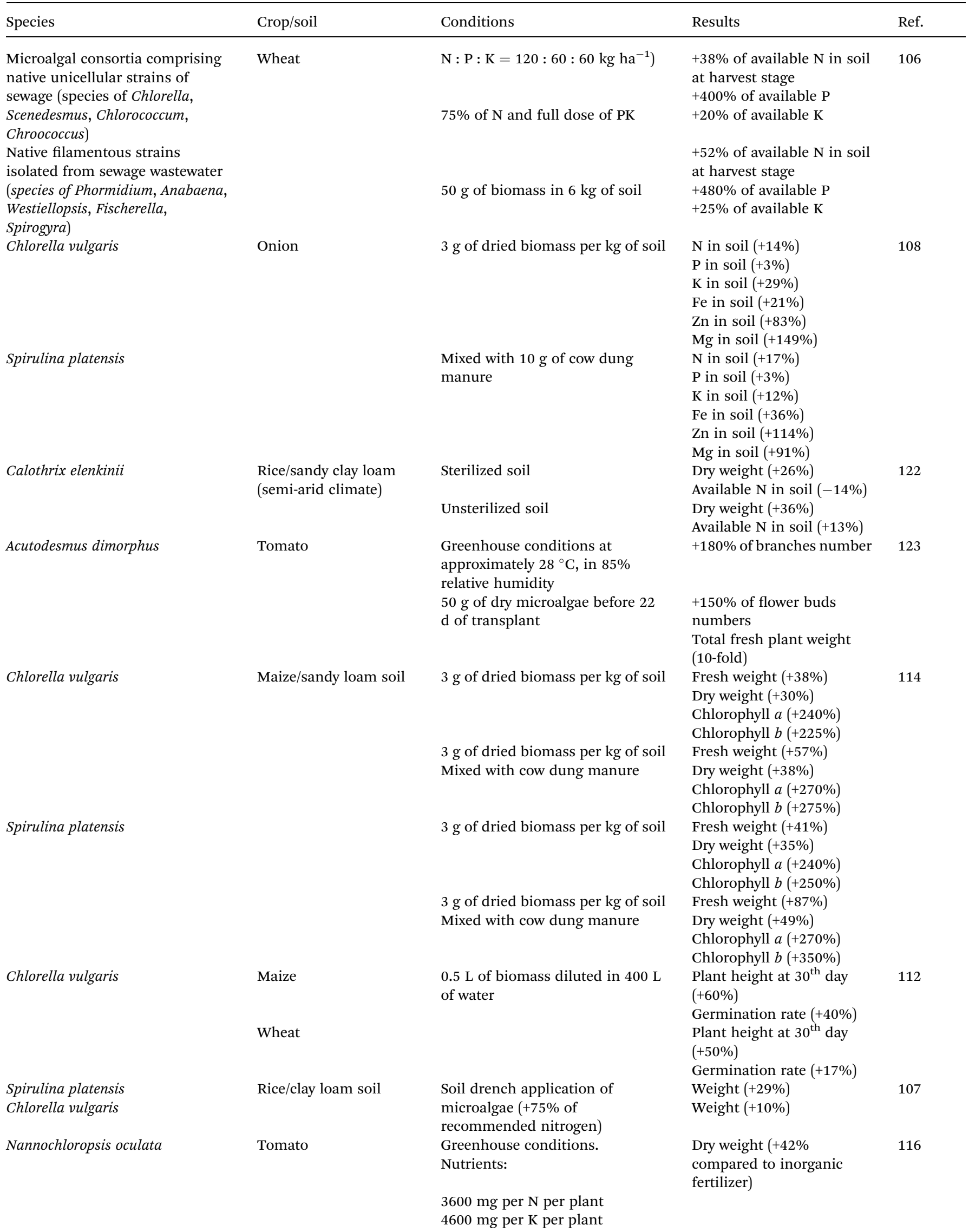


Table 3 (Contd.)

\begin{tabular}{|c|c|c|c|c|}
\hline Species & Crop/soil & Conditions & Results & Ref. \\
\hline & & & $\begin{array}{l}\text { Carotenoids }(+50 \% \\
\text { compared to inorganic } \\
\text { fertilizer) }\end{array}$ & \\
\hline & & Inorganic fertilizer & Dry weight $(+23 \%$ & \\
\hline & & $678 \mathrm{mg}$ per P per plant & $\begin{array}{l}\text { compared to organic } \\
\text { fertilizer) }\end{array}$ & \\
\hline & & $\begin{array}{l}\text { Organic fertilizer: } 1746 \mathrm{mg} \text { P per } \\
\text { plant }\end{array}$ & $\begin{array}{l}\text { Carotenoids (no significant } \\
\text { difference compared to }\end{array}$ & \\
\hline & & Microalgae: 7900 mgP per plant & organic fertilizer) & \\
\hline \multirow[t]{4}{*}{ S. platensis } & Red spinach & $5 \mathrm{~g}$ of biomass per pot & Chlorophyll (+34\%) & 115 \\
\hline & & & Dry weigh $(+156 \%)$ & \\
\hline & & $5 \mathrm{~g}$ of biomass per pot & Chlorophyll (+54\%) & \\
\hline & & $\begin{array}{l}\text { +Triple Pro } 15-15-15,(0.3 \mathrm{~g} \text { per pot } \\
\text { per week) }\end{array}$ & Dry weigh $(+430 \%)$ & \\
\hline \multirow[t]{2}{*}{ Phaeodactylum tricornutum } & Bell pepper & $\mathrm{NaCl}(0 \mathrm{mM})$ & Germination $(+36 \%)$ & 113 \\
\hline & & $\mathrm{NaCl}(25 \mathrm{mM})$ & $\begin{array}{l}\text { No significant effect on } \\
\text { germination }\end{array}$ & \\
\hline \multirow[t]{2}{*}{ Dunaliella salina } & & $\mathrm{NaCl}(0 \mathrm{mM})$ & Germination $(+36 \%)$ & \\
\hline & & $\mathrm{NaCl}(25 \mathrm{mM})$ & $\begin{array}{l}\text { No significant effect on } \\
\text { germination }\end{array}$ & \\
\hline Chlorella sp. & Wheat/Desert soil & Microalgae grown in wastewater & Plant height $(+100 \%)$ & 103 \\
\hline Scenedesmus sp. & & & Plant height (+100\%) & \\
\hline Tetraselmis sp. & & Microalgae grown in seawater & Plant height $(+77 \%)$ & \\
\hline Nannochloropsis sp. & & & Plant height $(+100 \%)$ & \\
\hline \multirow[t]{2}{*}{ Monoraphidium sp. } & Tomato & $170 \mathrm{~kg}$ per $\mathrm{N}$ per ha & Plant weigh $(+32 \%)$ & 117 \\
\hline & & & $\begin{array}{l}\text { No effect on elemental } \\
\text { composition of plants }\end{array}$ & \\
\hline \multirow[t]{6}{*}{ Chlorella vulgaris } & Lettuce & Fresh $0.5 \mathrm{~g} \mathrm{~kg}^{-1}$ of soil & $-4 \%$ of total pigments & 119 \\
\hline & & $1 \mathrm{~g} \mathrm{~kg}^{-1}$ of soil & $+30 \%$ of total pigments & \\
\hline & & $2 \mathrm{~g} \mathrm{~kg}^{-1}$ of soil & $-4 \%$ of total pigments & \\
\hline & & Dried $0.5 \mathrm{~g} \mathrm{~kg}^{-1}$ of soil & $-9 \%$ of total pigments & \\
\hline & & $1 \mathrm{~g} \mathrm{~kg}^{-1}$ of soil & $-17 \%$ of total pigments & \\
\hline & & $2 \mathrm{~g} \mathrm{~kg}^{-1}$ of soil & $-14 \%$ of total pigments & \\
\hline
\end{tabular}

compared to untreated microalgae digestate, while the digestate of thermally pretreated microalgae had no impact on cress growth, ${ }^{\mathbf{1 3 0}}$ which suggest that the impact of codigestion with sludge on digestate agronomic properties was higher compared to the impact of pretreatment.

\subsection{Digestate as culture medium}

As seen previously, mixotrophic mode was reported to be more advantageous concerning microalgae growth and productivity. As this mode requires nutrients and organic matter supply, wastewater, industrial and agricultural effluents as well as digestates can be used as cheap culture media for microalgae growth. ${ }^{\mathbf{1 2 4}}$ The optimized use of effluents as culture media can improve the cost-effectiveness of microalgae cultivation making it more competitive with industrial fertilizers. ${ }^{\mathbf{1 2 4}}$ At the same time, the treatment of these effluents can be carried out.

In fact, living or non-living algae can be used in heavy metals removal from wastewater. Biosorption using microalgae is more environmentally friendly if compared to surface modified biomass. It is also more cost effective with the possibility of converting the heavy metals to low toxic forms. ${ }^{135}$ Using Chlorella vulgaris as biosorbent for $\mathrm{Cr}(\mathrm{vI})$ removal was found to be effective. At a dose of $1 \mathrm{~g} \mathrm{~L}^{-1}$ of algae and $50 \mathrm{mg}$ of Cr per L for 4 hours and $\mathrm{pH} 2$, the biosorption efficiency achieved $80 \% .^{\mathbf{1 3 6}}$ Under the same conditions, Spirulina sp. was found to remove effectively chromium after $30 \mathrm{~min} .{ }^{137}$ Thus, the efficiency of heavy metal biosorption and operating conditions can be different from species to others. Also, pretreatment of microalgae may be needed to enhance its selective removal. ${ }^{\mathbf{1 3 8}}$

Carbon, phosphorus and nitrogen from wastewater can also be removed by microalgae. Chlorella vulgaris and Scenedesmus obliquus are among the most studied biomasses for nutrients removal. Galan et al. (2020) reported that phosphorus and ammonium were removed from agricultural runoff with $100 \%$ and $93 \%$ efficiency respectively. ${ }^{139}$ However, the use of microalgae for pesticides such as terbutryn, diuron, diazinon and imidacloprid removal was not effective. ${ }^{\mathbf{1 3 9}}$ Moreover, the use of microalgae for biosorption of toxic compounds can highly affect its ultimate conversion to biofuels, use for food or agriculture. ${ }^{\mathbf{1 3 8}}$ For this reason, the high nutrients and turbidity of the digestate can hinder its use as medium for microalgae culture. As light is the limiting factor for microalgae growth, suspended solids in digestate can absorb light and then increase its attenuation. ${ }^{\mathbf{1 4 0}}$ High turbidity can be overcome by pre-treating digestate with 
Table 4 Digestate properties adapted from literature

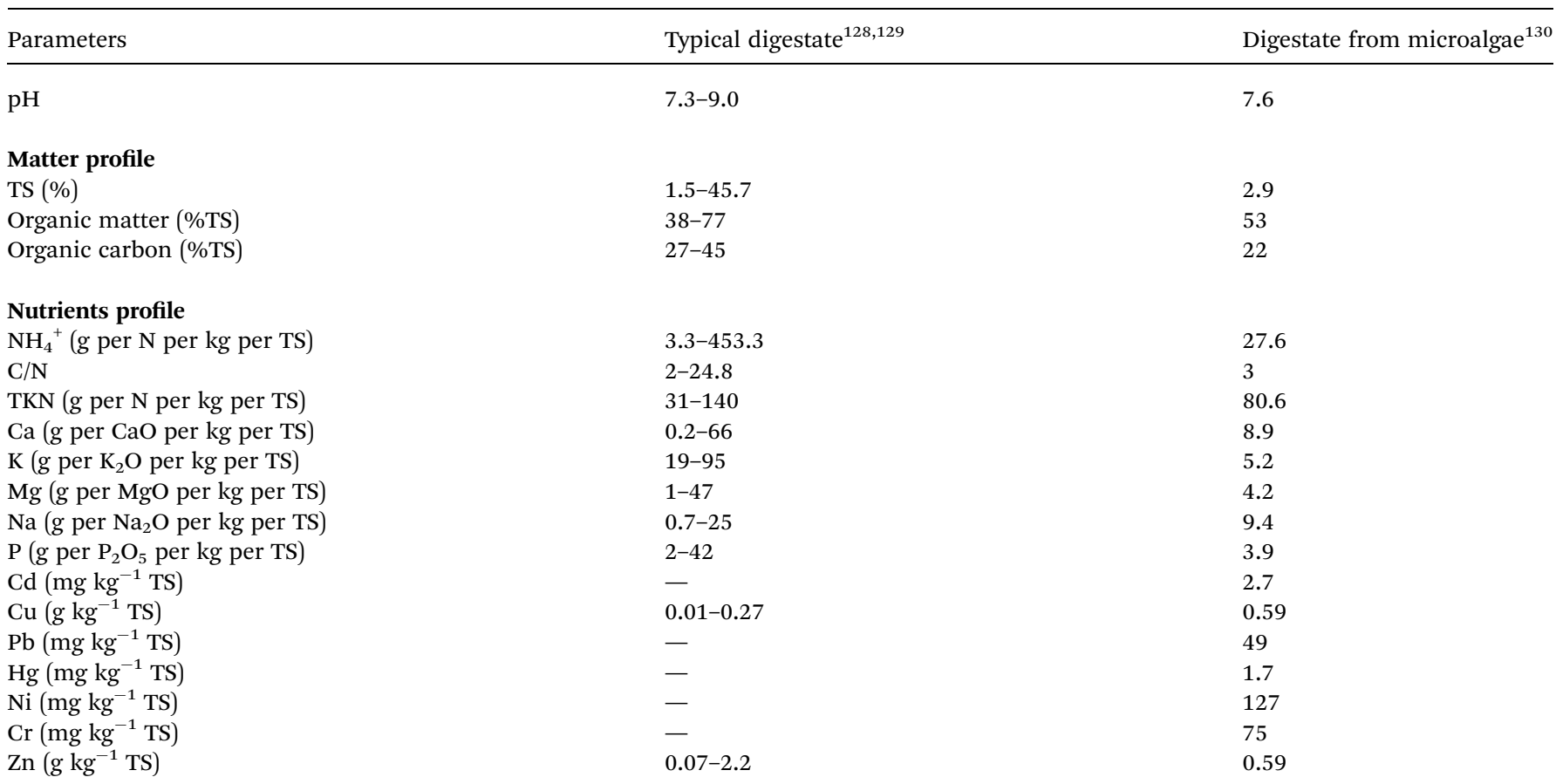

centrifugation and filtration for examples which generates additional costs. ${ }^{141}$ However, the most used method to reduce turbidity is dilution. Rajagopal et al. (2021) reported that above a digestate concentration of $30 \%$, the high $\mathrm{N}$ content inhibited microalgae growth. ${ }^{\mathbf{1 4 2}}$ Dilution is also used to reduce the ammonia supply when its concentration in digestate exceed $100 \mathrm{mg} \mathrm{L}^{-1} \cdot{ }^{141}$ In the same manner, $\mathrm{C}$ to $\mathrm{N}$ and $\mathrm{N}$ to $\mathrm{P}$ ratios in digestates should be maintained into the optimal ranges of 4-8 and 14-16 respectively for an effective microalgae growth. ${ }^{\mathbf{1 4 1}}$ Also, if $\mathrm{CO}_{2}$ from anaerobic digestion is used for microalgae growth, attention should be paid to high concentrations of $\mathrm{NO}_{x}$ and $\mathrm{SO}_{x}{ }^{143}$ Many studies have been carried out to assess the effect of digestate on microalgae growth as reported in Table 5. Digestate from different sources: manure, crop residues or municipal wastes showed different impacts depending on microalgae species, the dilution factor and growth conditions. Generally, a dilution factor above $1: 10$ is used. ${ }^{144}$ Jimenez et al. (2020) reported that an increase in dilution factor enhanced the specific growth of Monoraphidium sp. as well as ammonium and phosphorus removal efficiencies. ${ }^{117}$ However, in the case of using digestate from cattle slurry and cheese whey mixture, the final specific growth of three different species of microalgae was found to be reduced when increasing dilution factor. In fact, growth was faster when higher dilution factors were used, but after the $7^{\text {th }}$ day, microalgae growth was slowed down which may be due to low nutrients concentrations in digestate and their fast consumption by microalgae. ${ }^{\mathbf{1 4 5}}$ However, the effect of digestate dilution on biomass growth can depend on microalgae strains. ${ }^{\mathbf{1 4 6}}$ In the case of Synechocystis sp., biomass productivity was improved by digestate dilution, contrarily to $N$. salina. ${ }^{\mathbf{1 4 6}}$ Digestate source may also affect microalgae growth, which is obviously related to the composition of the substrates. ${ }^{6}$

Compared to synthetic media, digestate was reported to have a higher impact on microalgae growth and productivity. ${ }^{\mathbf{1 4 7}}$ However, Kobayashi et al. (2013) found that biomass productivity after digestate addition was $40 \%$ lower compared to Bold's Basal medium. This latter is rich in mineral nutrients and vitamins which may be more profitable compared to a diluted digestate. ${ }^{\mathbf{1 4 8}}$ Nitrogen removal from digestate was also found to increase when increasing digestate dilution. ${ }^{\mathbf{1 4 8 , 1 4 9}}$ The impact of using digestate as nutrient source for microalgae growth was found to be profitable for its agriculture application. ${ }^{117}$ However, further studies should be carried out to determine to what extent this practice can be beneficial for the soil and the plant.

Rajagopal et al. (2021) studied the energy and nutrient benefit of coupling anaerobic digestion of chicken manure and microalgae production using liquid digestate. It was suggested that the nutrients provided by the digestates were sufficiently beneficial to have microalgae exploitable in the extraction of high value-added molecules. ${ }^{\mathbf{1 4 2}}$

\section{Challenges and recommendations}

The main challenges of microalgae anaerobic digestion are: (i) low yield of biomass; (ii) inhibition occurrence due to high $\mathrm{N}$ and salinity content in microalgae is marine; and (iii) need for pretreatment in case of microalgae with thick cell wall; (iv) cultivation and harvesting costs.

Anaerobic digestion process requires the use of an available organic matter to feed the digester in case of continuous and 
Table 5 Digestate use as nutrient source for microalgae growth

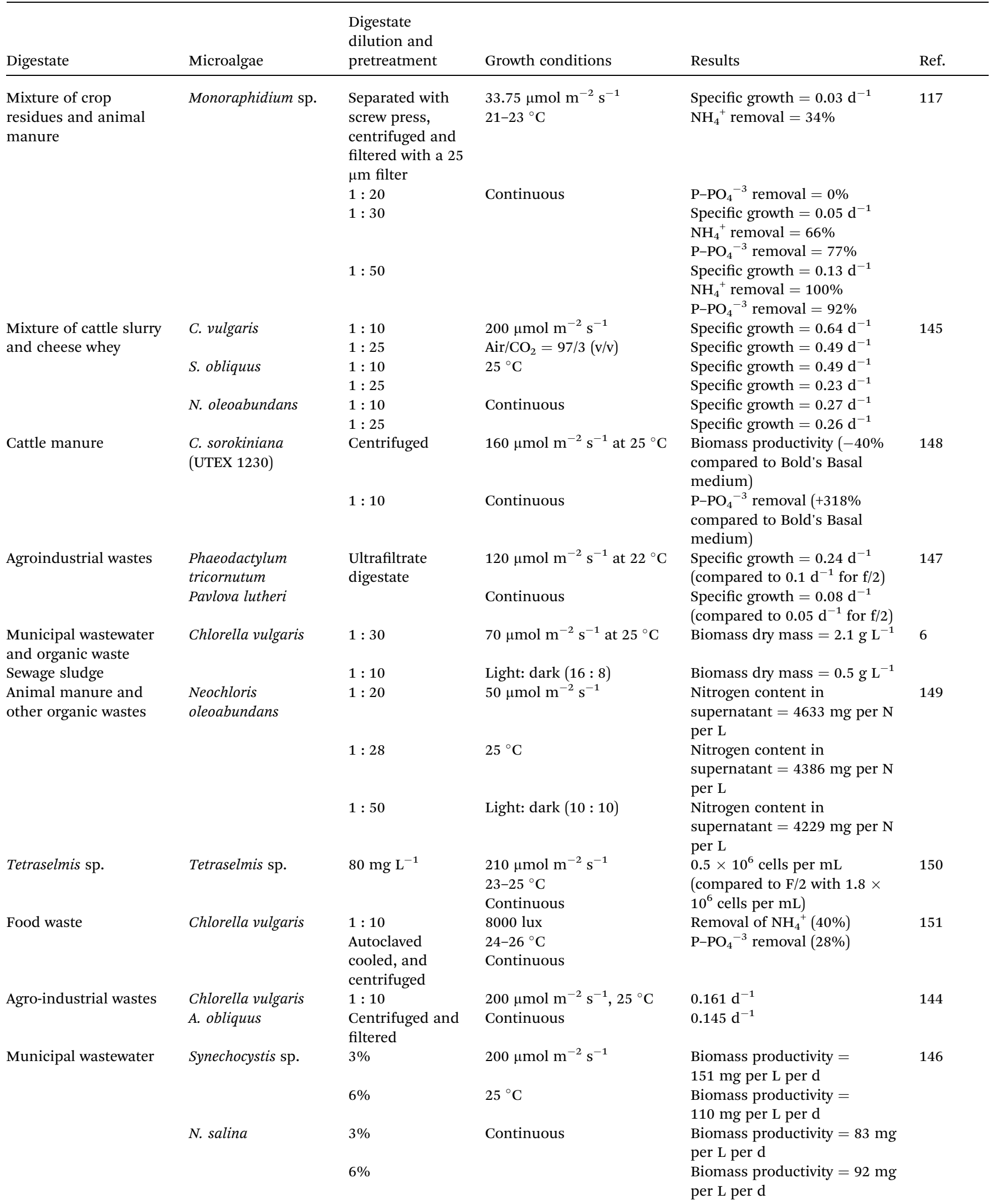


semi-continuous reactors. As microalgal biomass yield is generally around $0.5 \mathrm{~g} \mathrm{~L}^{-1},{ }^{152}$ monodigestion of microalgae does not appear to be a profitable way to valorize microalgal biomass because of the low methane productivity. Higher biomass recovery efficiency require the use of more expensive harvesting techniques such as centrifugation, ${ }^{153}$ which is only preferred in the case of microalgae for high value-added products. ${ }^{152}$

Moreover, salinity can highly affect methanogenesis which may reduce methane production by $50 \%$ at a $\mathrm{Na}^{+}$concentration around $10 \mathrm{~g} \mathrm{~L}^{-1} \cdot{ }^{154}$ As the optimal sodium content is around 0.23-0.35 $\mathrm{g} \mathrm{L}^{-1}$, monodigestion of marine microalgae can lead to operational problems and even to the failure of the anaerobic digestion process. ${ }^{155}$ Co-digestion can, however, remedy this problem by using a co-substrate with a lower salt content such as sewage sludge or agricultural residues. Codigestion is also beneficial in case of protein-rich microalgae in order to avoid ammonia inhibition related to protein degradation through anaerobic digestion stages. ${ }^{156}$ In fact, above $1.5 \mathrm{~g}$ of ammonium per liter, a reduction of methane production can occur. ${ }^{157}$ In general, codigestion enables the dilution of potential toxic elements that may hinder anerobic digestion, in addition, it can regulate the $\mathrm{C}$ to $\mathrm{N}$ ratio leading to more optimal biogas production. Some other problems related to microalgal biomass bioaccessibility can be remedied when applying pretreatments as previously mentioned. The use of an effective pretreatment may require energy and chemicals consumption which generate additional operational costs. Energy and nutrients consumption during cultivation stage is among the most important concerns limiting the application of $\mathrm{AD}$ at large scale.
Previously, wastewater and digestate use as culture media showed positive impacts on microalgae growth when a dilution is carried out to reduce the toxicity of the elements that may be present in these liquids. In addition, the use of a renewable energy source such as solar or wind power to cover the needs of the upstream processes can greatly reduce the energy inputs. ${ }^{158}$ So far, microalgae AD is not really economically viable. ${ }^{5}$ Codigestion of microalgae residues after lipids or proteins extraction can be more interesting, even if the methanogenic potential of these molecules will be deducted from that of the raw microalgal biomass. ${ }^{159}$ Anaerobic digestion and the use of microalgal residues as fertilizers after extraction of molecules of interest are rather considered as management strategies in the framework of the circular economy.

Fig. 3 presents a suggested system for a more sustainable and cost-effective valorization of microalgae. As mentioned previously, the co-digestion of agricultural or municipal solid wastes with microalgae residues after extraction of lipids, proteins or any other value-added molecules. The generated digestate can be then, used as fertilizer (solid fraction) or as nutrient source for microalgae growth (liquid fraction). The main advantage of this system is the recovery of energy, nutrients and $\mathrm{CO}_{2}$ from anaerobic digester which are required for microalgae growth. In addition, to the treatment of microalgae residues which suggest that this process can reach the "Zero waste" objective if well optimized. However, a complete study needs to be carried out regarding technical, economic and energy calculations before establishing technological solutions in large-scale biogas production facilities. ${ }^{\mathbf{1 7}}$ This study should also take into account potential co-substrates that can boost

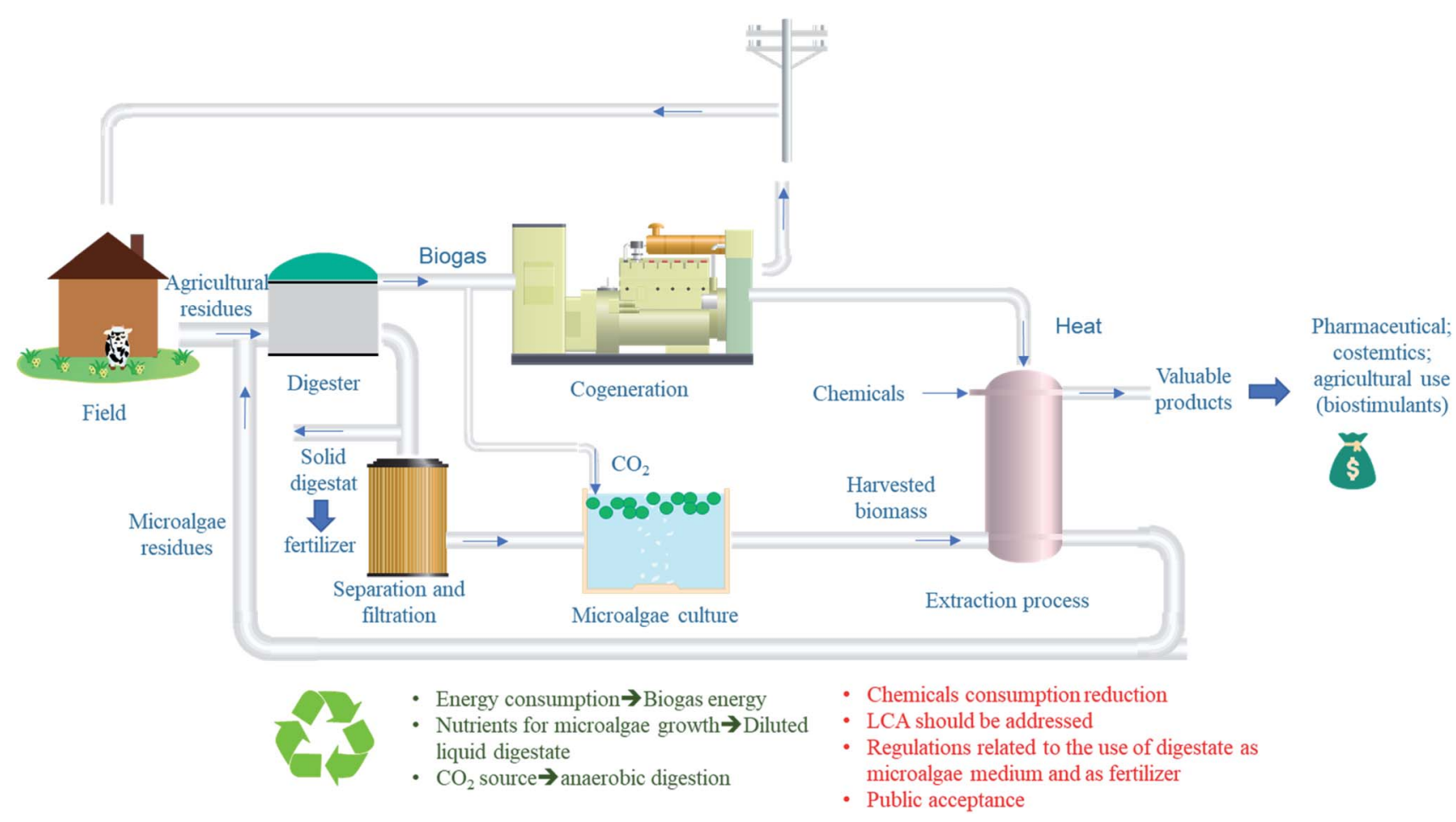

Fig. 3 Co-digestion and agronomic applications to valorize microalgae-derived residues. 
methane production, their availability in a given geographical area and the costs of transporting these substrates and microalgae. A possible solution to reduce these costs would be the production of microalgae at the WWTP or within the farm in the case of using agricultural residues as cosubstrates. Moreover, sanitary aspect of using digestate for microalgae nutrients should be studied as well as its impact on microalgae properties and its eventual commercial value. As far as regulations are concerned, the use of microalgae for agronomic purposes and their residues should be reviewed and introduced. It is also necessary to study at what level the public will accept this practice, especially as some of the by-products will be returned to the soil.

\section{Conclusions}

The production of microalgae and their integration into a biorefinery system is among the emerging and much studied strategies. However, their industrial application remains limited, as does their energy and economic efficiency. It is therefore recommended (i) to optimize the conditions of the different stages of the process to favor metabolites accumulation, (ii) to recycle nutrients from anaerobic digestate and $\mathrm{CO}_{2}$ from biogas to reduce microalgae cultivation costs, (iii) to use microalgae residues for biogas production and soil fertilization for its organic and mineral components while meeting the environmental and economic requirements of this practice.

\section{Abbreviations}

$\begin{array}{ll}\text { AD } & \text { Anaerobic digestion } \\ \text { ATP } & \text { Adenosine triphosphate } \\ \text { NADPH } & \text { Nicotinamide adenine dinucleotide phosphate } \\ \text { PBR } & \text { Photobioreactor } \\ \text { TS } & \text { Total solids } \\ \text { VS } & \text { Volatile solids } \\ \text { WAS } & \text { Waste activated sludge } \\ \text { WWTP } & \text { Wastewater treatment plant }\end{array}$

\section{Conflicts of interest}

There are no conflicts to declare.

\section{Acknowledgements}

Special thanks to the University Mohamed VI Polytechnic (UM6P) for providing financial support for this work.

\section{References}

1 E. Jankowska, A. K. Sahu and P. Oleskowicz-Popiel, Renewable Sustainable Energy Rev., 2017, 75, 692-709.

2 A. K. Patel, J. M. Joun, M. E. Hong and S. J. Sim, Bioresour. Technol., 2019, 282, 245-253.
3 F. Passos, A. Hom-Diaz, P. Blanquez, T. Vicent and I. Ferrer, Bioresour. Technol., 2016, 199, 347-351.

4 M. Solé-Bundó, F. Passos, M. S. Romero-Güiza, I. Ferrer and S. Astals, Renewable Sustainable Energy Rev., 2019, 112, 471482.

5 R. Ganesh Saratale, G. Kumar, R. Banu, A. Xia, S. Periyasamy and G. Dattatraya Saratale, Bioresour. Technol., 2018, 262, 319-332.

6 L. Zuliani, N. Frison, A. Jelic, F. Fatone, D. Bolzonella and M. Ballottari, Int. J. Mol. Sci., 2016, 17, 1692.

7 P. Geada, V. Vasconcelos, A. Vicente and B. Fernandes, in Algal Green Chemistry, Elsevier, 2017, pp. 257-284.

8 S. M. Tibbetts, J. E. Milley and S. P. Lall, J. Appl. Phycol., 2015, 27, 1109-1119.

9 Microalgae Biotechnology for Food, Health and High Value Products, ed. M. A. Alam, J.-L. Xu and Z. Wang, Springer Singapore, Singapore, 2020.

10 C. González-Fernández, B. Sialve, N. Bernet and J.-P. Steyer, Biofuels, Bioprod. Biorefin., 2012, 6, 205-218.

11 H. Du, J. Ren, Z. Li, H. Zhang, K. Wang, B. Lin, S. Zheng, C. Zhao, C. Meng and Z. Gao, Aquacult. Int., 2020, 28, 1319-1340.

12 J. D. Gouveia, J. Ruiz, L. A. M. van den Broek, T. Hesselink, S. Peters, D. M. M. Kleinegris, A. G. Smith, D. van der Veen, M. J. Barbosa and R. H. Wijffels, J. Biotechnol., 2017, 248, 77-86.

13 Biofuels Production - Sustainability and Advances in Microbial Bioresources, ed. A. N. Yadav, A. A. Rastegari, N. Yadav and R. Gaur, Springer International Publishing, Cham, 2020, vol. 11.

14 S. P. Choi, M. T. Nguyen and S. J. Sim, Bioresour. Technol., 2010, 101, 5330-5336.

15 Y. Li, D. Han, G. Hu, M. Sommerfeld and Q. Hu, Biotechnol. Bioeng., 2010, 107, 258-268.

16 A. Kuila and M. Mukhopadhyay, Biorefinery Production Technologies for Chemicals and Energy, Wiley, 2020.

17 H. M. Zabed, S. Akter, J. Yun, G. Zhang, Y. Zhang and X. Qi, Renewable Sustainable Energy Rev., 2020, 117, 109503.

18 F. A. Q. Sayegh, N. Radi and D. J. S. Montagnes, Aquaculture, 2007, 273, 665-678.

19 Y. Yan, X. Li, G. Wang, X. Gui, G. Li, F. Su, X. Wang and T. Liu, Appl. Energy, 2014, 113, 1614-1631.

20 L. German-Báez, M. Valdez-Flores, J. Félix-Medina, C. Norzagaray-Valenzuela, D. Santos-Ballardo, C. ReyesMoreno, L. Shelton and A. Valdez-Ortiz, Food Sci. Technol. Int., 2017, 23, 681-689.

21 D.-T. Tran, C.-L. Chen and J.-S. Chang, Bioresour. Technol., 2013, 135, 213-221.

22 T. Liu, J. Wang, Q. Hu, P. Cheng, B. Ji, J. Liu, Y. Chen, W. Zhang, X. Chen, L. Chen, L. Gao, C. Ji and H. Wang, Bioresour. Technol., 2013, 127, 216-222.

23 P. Varshney, J. Beardall, S. Bhattacharya and P. P. Wangikar, Algal Res., 2018, 30, 28-37.

24 S.-H. Ho, C.-Y. Chen and J.-S. Chang, Bioresour. Technol., 2012, 113, 244-252.

25 X. Sun, Y. Cao, H. Xu, Y. Liu, J. Sun, D. Qiao and Y. Cao, Bioresour. Technol., 2014, 155, 204-212. 
26 A. K. Patel, Y. Y. Choi and S. J. Sim, Bioresour. Technol., 2020, 300, 122741.

27 A. Richmond, Z. Cheng-Wu and Y. Zarmi, Biomol. Eng., 2003, 20, 229-236.

28 D. P. Kurpan Nogueira, A. F. Silva, O. Q. F. Araújo and R. M. Chaloub, Biomass Bioenergy, 2015, 72, 280-287.

29 L. F. Wu, P. C. Chen and C. M. Lee, Int. Biodeterior. Biodegrad., 2013, 85, 506-510.

30 S.-H. Ho, X. Ye, T. Hasunuma, J.-S. Chang and A. Kondo, Biotechnol. Adv., 2014, 32, 1448-1459.

31 M. I. Khan, J. H. Shin and J. D. Kim, Microb. Cell Fact., 2018, 17,36 .

32 K. Ying, K. D. James Gilmour and W. B. Zimmerman, J. Microb. Biochem. Technol., 2014, 6, 167-173.

33 M. Taraldsvik and S. Myklestad, Eur. J. Phycol., 2000, 35, 189-194.

34 Z. Lari, N. Moradi-kheibari, H. Ahmadzadeh, P. Abrishamchi, N. R. Moheimani and M. A. Murry, J. Appl. Phycol., 2016, 28, 3235-3250.

35 G. Singh and S. K. Patidar, BioEnergy Res., 2020, DOI: 10.1007/s12155-020-10195-8.

36 A. Khanra, S. Vasistha, P. Kumar and M. P. Rai, 3 Biotech, 2020, 10, 331.

37 C. Y. B. Oliveira, E. B. D'Alessandro, N. R. Antoniosi Filho, R. G. Lopes and R. B. Derner, Sci. Total Environ., 2020, 143476.

38 B. Behera, A. Acharya, I. A. Gargey, N. Aly and B. Paramasivan, Bioresource Technology Reports, 2019, 5, 297-316.

39 M. J. Zarrinmehr, O. Farhadian, F. P. Heyrati, J. Keramat, E. Koutra, M. Kornaros and E. Daneshvar, Egypt. J. Aquat. Res., 2020, 46, 153-158.

40 G. Markou, Appl. Biochem. Biotechnol., 2014, 172, 27582768.

41 X. Li, W. Li, J. Zhai, H. Wei and Q. Wang, Bioresour. Technol., 2019, 273, 368-376.

42 K. Goiris, W. Van Colen, I. Wilches, F. León-Tamariz, L. De Cooman and K. Muylaert, Algal Res., 2015, 7, 51-57.

43 S.-H. Ho, P.-J. Li, C.-C. Liu and J.-S. Chang, Bioresour. Technol., 2013, 145, 142-149.

44 A. Ghosh, S. Sarkar, K. Gayen and T. K. Bhowmick, Environ. Prog. Sustainable Energy, 2020, 39, e13378.

45 V. Shashirekha, M. Sivakumar and S. Seshadri, Energy, Ecology and Environment, 2016, 1, 283-295.

46 J. Liu, Y. Qiu, L. He, K. Luo and Z. Wang, Arch. Microbiol., 2021, 203, 733-740.

47 H.-X. Weng, Y.-C. Qin, X.-W. Sun and J.-F. Chen, Environ. Geol., 2008, 55, 1431-1436.

48 N.-H. Norsker, in Handbook of Microalgae-Based Processes and Products, Elsevier, 2020, pp. 861-883.

49 G. Zuccaro, A. Yousuf, A. Pollio and J.-P. Steyer, in Microalgae Cultivation for Biofuels Production, Elsevier, 2020, pp. 11-29.

50 J. Pruvost, F. Le Borgne, A. Artu, J.-F. Cornet and J. Legrand, in Advances in Chemical Engineering, Elsevier, 2016, vol. 48, pp. 257-310.
51 D. S. Wágner, B. Valverde-Pérez and B. Gy. Plósz, Algal Res., 2018, 35, 488-499.

52 M. Marsullo, A. Mian, A. V. Ensinas, G. Manente, A. Lazzaretto and F. Marechal, Frontiers in Energy Research, 2015, 3, 41.

53 F. G. Acién, E. Molina, A. Reis, G. Torzillo, G. C. Zittelli, C. Sepúlveda and J. Masojídek, in Microalgae-Based Biofuels and Bioproducts, Elsevier, 2017, pp. 1-44.

54 D. Chiaramonti, M. Prussi, D. Casini, M. R. Tredici, L. Rodolfi, N. Bassi, G. C. Zittelli and P. Bondioli, Appl. Energy, 2013, 102, 101-111.

55 L. Christenson and R. Sims, Biotechnol. Adv., 2011, 29, 686702.

56 G. S. Murthy, in Biofuels, Elsevier, 2011, pp. 415-437.

57 W. Blanken, M. Cuaresma, R. H. Wijffels and M. Janssen, Algal Res., 2013, 2, 333-340.

58 Z. Zhu, J. Jiang and Y. Fa, Molecules, 2020, 25, 5220.

59 S. Park, S. W. Van Ginkel, P. Pradeep, T. Igou, C. Yi, T. Snell and Y. Chen, Water Environ. Res., 2016, 88, 70-78.

60 J. G. Day, Y. Gong and Q. Hu, Algal Res., 2017, 27, 356-365.

61 M. Ma, D. Yuan, Y. He, M. Park, Y. Gong and Q. Hu, Algal Res., 2017, 26, 436-444.

62 C. L. Fisher, C. S. Ward, P. D. Lane, J. A. Kimbrel, K. L. Sale, R. K. Stuart, X. Mayali and T. W. Lane, Algal Res., 2019, 40, 101500.

63 J. H. Mussgnug, V. Klassen, A. Schlüter and O. Kruse, J. Biotechnol., 2010, 150, 51-56.

64 N. O. Santos, S. M. Oliveira, L. C. Alves and M. C. Cammarota, Bioresour. Technol., 2014, 157, 60-67.

65 L. Appels, J. Baeyens, J. Degrève and R. Dewil, Prog. Energy Combust. Sci., 2008, 34, 755-781.

66 H. Carrere, G. Antonopoulou, R. Affes, F. Passos, A. Battimelli, G. Lyberatos and I. Ferrer, Bioresour. Technol., 2016, 199, 386-397.

67 C. Zamalloa, N. Boon and W. Verstraete, Appl. Energy, 2012, 92, 733-738.

68 M. Anjos, B. D. Fernandes, A. A. Vicente, J. A. Teixeira and G. Dragone, Bioresour. Technol., 2013, 139, 149-154.

69 N. Hossain, J. Zaini, T. M. I. Mahlia and A. K. Azad, Renewable Energy, 2019, 131, 617-624.

70 P. Bohutskyi, T. A. Keller, D. Phan, M. L. Parris, M. Li, L. Richardson and A. M. Kopachevsky, Frontiers in Energy Research, 2019, 7, 47.

71 M. Taherzadeh and K. Karimi, Int. J. Mol. Sci., 2008, 9, 16211651.

72 H. G. Gerken, B. Donohoe and E. P. Knoshaug, Planta, 2013, 237, 239-253.

73 M. Audo, M. Paraschiv, C. Queffélec, I. Louvet, J. Hémez, F. Fayon, O. Lépine, J. Legrand, M. Tazerout, E. Chailleux and B. Bujoli, ACS Sustainable Chem. Eng., 2015, 3, 583-590.

74 C. Yuan, Y.-L. Zheng, W.-L. Zhang, R. He, Y. Fan, G.-R. Hu and F.-L. Li, J. Appl. Phycol., 2017, 29, 2789-2800.

75 L. Mendez, A. Mahdy, R. A. Timmers, M. Ballesteros and C. González-Fernández, Bioresour. Technol., 2013, 149, 136-141. 
76 S. Schwede, A. Kowalczyk, M. Gerber and R. Span, Influence of different cell disruption techniques on mono digestion of algal, 2011, pp. 41-47.

77 F. Passos, M. Solé, J. García and I. Ferrer, Appl. Energy, 2013, 108, 168-175.

78 M. P. Caporgno, M. Olkiewicz, C. Torras, J. Salvadó, E. Clavero and C. Bengoa, J. Environ. Manage., 2016, 177, 240-246.

79 S. Schwede, Z.-U. Rehman, M. Gerber, C. Theiss and R. Span, Bioresour. Technol., 2013, 143, 505-511.

80 G. Ciudad, O. Rubilar, L. Azócar, C. Toro, M. Cea, Á. Torres, A. Ribera and R. Navia, J. Biosci. Bioeng., 2014, 117, 75-80.

81 H. V. Kinnunen, P. E. P. Koskinen and J. Rintala, Bioresour. Technol., 2014, 155, 314-322.

82 A. Mahdy, L. Mendez, M. Ballesteros and C. GonzálezFernández, Bioresour. Technol., 2015, 184, 236-244.

83 D. Elalami, H. Carrere, F. Monlau, K. Abdelouahdi, A. Oukarroum and A. Barakat, Renewable Sustainable Energy Rev., 2019, 114, 109287.

84 D. Lu and X. J. Zhang, J. Environ. Eng., 2016, 142, 04016049. 85 M. Wang, A. K. Sahu, B. Rusten and C. Park, Bioresour. Technol., 2013, 142, 585-590.

86 M. Solé-Bundó, M. Garfí and I. Ferrer, Bioresour. Technol., 2020, 298, 122563.

87 M. Solé-Bundó, M. Garfí, V. Matamoros and I. Ferrer, Sci. Total Environ., 2019, 660, 974-981.

88 R. C. Anyanwu, C. Rodriguez, A. Durrant and A. G. Olabi, in Reference Module in Materials Science and Materials Engineering, Elsevier, 2018, p. B9780128035818093000.

89 Y. Zhang, G. S. Caldwell, A. M. Zealand and P. J. Sallis, Biochem. Eng. J., 2019, 143, 91-100.

90 M. Solé-Bundó, C. Eskicioglu, M. Garfí, H. Carrère and I. Ferrer, Bioresour. Technol., 2017, 237, 89-98.

91 W. Zhong, Z. Zhang, Y. Luo, W. Qiao, M. Xiao and M. Zhang, Bioresour. Technol., 2012, 114, 281-286.

92 F. Passos, P. H. M. Cordeiro, B. E. L. Baeta, S. F. de Aquino and S. I. Perez-Elvira, Bioresour. Technol., 2018, 253, 49-54.

93 C. Herrmann, N. Kalita, D. Wall, A. Xia and J. D. Murphy, Bioresour. Technol., 2016, 214, 328-337.

94 M. J. Fernández-Rodríguez, D. de la Lama-Calvente, A. Jiménez-Rodríguez, R. Borja and B. Rincón, J. Appl. Phycol., 2021, 33, 419-429.

95 S. Astals, R. S. Musenze, X. Bai, S. Tannock, S. Tait, S. Pratt and P. D. Jensen, Bioresour. Technol., 2015, 181, 97-104.

96 A. Ajeej, J. V. Thanikal, C. M. Narayanan and R. Senthil Kumar, Renewable Sustainable Energy Rev., 2015, 50, 270276.

97 E. A. Ehimen, S. Connaughton, Z. Sun and G. C. Carrington, GCB Bioenergy, 2009, 1, 371-381.

98 R. Avila, E. Carrero, E. Crivillés, M. Mercader, T. Vicent and P. Blánquez, Algal Res., 2020, 50, 101965.

99 S. Kavitha, P. Subbulakshmi, J. Rajesh Banu, M. Gobi and I. Tae Yeom, Bioresour. Technol., 2017, 233, 34-43.

100 S. Abinandan, S. R. Subashchandrabose, K. Venkateswarlu and M. Megharaj, Crit. Rev. Biotechnol., 2019, 39, 981-998.

101 N. Renuka, A. Guldhe, R. Prasanna, P. Singh and F. Bux, Biotechnol. Adv., 2018, 36, 1255-1273.
102 E. Yilmaz and M. Sönmez, Soil Tillage Res., 2017, 168, 118124.

103 P. Das, M. A. Quadir, M. I. Thaher, G. S. H. S. Alghasal and H. M. S. J. Aljabri, Int. J. Environ. Sci. Technol., 2019, 16, 3355-3364.

104 V. Barone, I. Puglisi, F. Fragalà, P. Stevanato and A. Baglieri, Arch. Agron. Soil Sci., 2019, 65, 712-726.

105 I. Perera, S. R. Subashchandrabose, K. Venkateswarlu, R. Naidu and M. Megharaj, Appl. Microbiol. Biotechnol., 2018, 102, 7351-7363.

106 N. Renuka, R. Prasanna, A. Sood, A. S. Ahluwalia, R. Bansal, S. Babu, R. Singh, Y. S. Shivay and L. Nain, Environ. Sci. Pollut. Res., 2016, 23, 6608-6620.

107 R. Dineshkumar, R. Kumaravel, J. Gopalsamy, M. N. A. Sikder and P. Sampathkumar, Waste Biomass Valorization, 2018, 9, 793-800.

108 R. Dineshkumar, J. Subramanian, A. Arumugam, A. Ahamed Rasheeq and P. Sampathkumar, Waste Biomass Valorization, 2020, 11, 77-87.

109 S. Geisen, E. A. D. Mitchell, S. Adl, M. Bonkowski, M. Dunthorn, F. Ekelund, L. D. Fernández, A. Jousset, V. Krashevska, D. Singer, F. W. Spiegel, J. Walochnik and E. Lara, FEMS Microbiol. Rev., 2018, 42, 293-323.

110 L. A. Lewis and F. R. Trainor, Phycologia, 2012, 51, 662-665. 111 A. L. Gonçalves, Appl. Sci., 2021, 11, 871.

112 O. Uysal, F. O. Uysal and K. Ekinci, European Journal of Sustainable Development, 2015, 4(2), 77.

113 M. A. Guzmán-Murillo, F. Ascencio and J. A. LarrinagaMayoral, Protoplasma, 2013, 250, 33-42.

114 R. Dineshkumar, J. Subramanian, J. Gopalsamy, P. Jayasingam, A. Arumugam, S. Kannadasan and P. Sampathkumar, Waste Biomass Valorization, 2019, 10, 1101-1110.

115 S. C. Wuang, M. C. Khin, P. Q. D. Chua and Y. D. Luo, Algal Res., 2016, 15, 59-64.

116 J. Coppens, O. Grunert, S. Van Den Hende, I. Vanhoutte, N. Boon, G. Haesaert and L. De Gelder, J. Appl. Phycol., 2016, 28, 2367-2377.

117 R. Jimenez, G. Markou, S. Tayibi, A. Barakat, C. Chapsal and F. Monlau, Appl. Sci., 2020, 10, 3890.

118 P. Deepika and D. MubarakAli, Biocatal. Agric. Biotechnol., 2020, 28, 101701.

119 F. A. Faheed and Z. Abd-El Fattah, J. Agri. Soc. Sci., 2008, 4, 165-169.

120 B. Górka, K. Korzeniowska, J. Lipok and P. P. Wieczorek, in Algae Biomass: Characteristics and Applications, ed. $\mathrm{K}$. Chojnacka, P. P. Wieczorek, G. Schroeder and I. Michalak, Springer International Publishing, Cham, 2018, pp. 103-114.

121 K. V. Supraja, B. Behera and B. Paramasivan, Ind. Crops Prod., 2020, 151, 112453.

122 K. Ranjan, H. Priya, B. Ramakrishnan, R. Prasanna, S. Venkatachalam, S. Thapa, R. Tiwari, L. Nain, R. Singh and Y. S. Shivay, Applied Soil Ecology, 2016, 108, 195-203.

123 J. Garcia-Gonzalez and M. Sommerfeld, J. Appl. Phycol., 2016, 28, 1051-1061. 
124 D. Ronga, E. Biazzi, K. Parati, D. Carminati, E. Carminati and A. Tava, Agronomy, 2019, 9, 192.

125 G. Colla and Y. Rouphael, Agronomy, 2020, 10, 1240.

126 J. A. Alburquerque, C. de la Fuente, A. Ferrer-Costa, L. Carrasco, J. Cegarra, M. Abad and M. P. Bernal, Biomass Bioenergy, 2012, 40, 181-189.

127 J. A. Alburquerque, C. de la Fuente, M. Campoy, L. Carrasco, I. Nájera, C. Baixauli, F. Caravaca, A. Roldán, J. Cegarra and M. P. Bernal, Eur. J. Agron., 2012, 43, 119128.

128 F. Monlau, C. Sambusiti, E. Ficara, A. Aboulkas, A. Barakat and H. Carrère, Energy Environ. Sci., 2015, 8, 2600-2621.

129 R. Nkoa, Agron. Sustainable Dev., 2014, 34, 473-492.

130 M. Solé-Bundó, M. Cucina, M. Folch, J. Tàpias, G. Gigliotti, M. Garfí and I. Ferrer, Sci. Total Environ., 2017, 586, 1-9.

131 L. M. González-González, E. Eltanahy and P. M. Schenk, Algal Res., 2019, 41, 101534.

132 K. Güngör and K. G. Karthikeyan, Bioresour. Technol., 2008, 99, 425-436.

133 F. Passos and I. Ferrer, Water Res., 2015, 68, 364-373.

134 F. Passos and I. Ferrer, Environ. Sci. Technol., 2014, 48, 7171-7178.

135 K. G. Pavithra, P. S. Kumar, V. Jaikumar, K. H. Vardhan and P. SundarRajan, Environ. Chem. Lett., 2020, 18, 1905-1923.

136 G. Sibi, Green Energy Environ., 2016, 1, 172-177.

137 E. Gunasundari and P. Senthil Kumar, IET Nanobiotechnol., 2017, 11, 317-328.

138 S. Maryjoseph and B. Ketheesan, Case Studies in Chemical and Environmental Engineering, 2020, 2, 100046.

139 V. García, J. Päkkilä, H. Ojamo, E. Muurinen and R. L. Keiski, Renewable Sustainable Energy Rev., 2011, 15, 964-980.

140 L. Wang, Y. Li, P. Chen, M. Min, Y. Chen, J. Zhu and R. R. Ruan, Bioresour. Technol., 2010, 101, 2623-2628.

141 D. Chuka-ogwude, J. Ogbonna and N. R. Moheimani, Algal Res., 2020, 47, 101841.

142 R. Rajagopal, S. E. Mousavi, B. Goyette and S. Adhikary, Bioengineering, 2021, 8, 57.
143 A. Pires, G. Martinho and N.-B. Chang, J. Environ. Manage., 2011, 92, 1033-1050.

144 E. Koutra, C. N. Economou, P. Tsafrakidou and M. Kornaros, Trends Biotechnol., 2018, 36, 819-833.

145 M. Franchino, E. Comino, F. Bona and V. A. Riggio, Chemosphere, 2013, 92, 738-744.

146 T. Cai, X. Ge, S. Y. Park and Y. Li, Bioresour. Technol., 2013, 144, 255-260.

147 D. Veronesi, A. Ida, G. D. Imporzano and F. Adani, Chemical Engineering Transactions, 2015, 43, 1201-1206.

148 N. Kobayashi, E. A. Noel, A. Barnes, A. Watson, J. N. Rosenberg, G. Erickson and G. A. Oyler, Bioresour. Technol., 2013, 150, 377-386.

149 H. A. Abu Hajar, R. Guy Riefler and B. J. Stuart, Environmental Engineering Research, 2016, 21, 265-275.

150 M. Erkelens, A. J. Ward, A. S. Ball and D. M. Lewis, Bioresour. Technol., 2014, 167, 81-86.

151 P. Praveen, Y. Guo, H. Kang, C. Lefebvre and K.-C. Loh, Chem. Eng. J., 2018, 354, 905-912.

152 K. Muylaert, L. Bastiaens, D. Vandamme and L. Gouveia, in Microalgae-Based Biofuels and Bioproducts, Elsevier, 2017, pp. 113-132.

153 G. Singh and S. K. Patidar, J. Environ. Manage., 2018, 217, 499-508.

154 J. Milledge, B. Nielsen, S. Maneein and P. Harvey, Energies, 2019, 12, 1166.

155 F. TorresRincón, B. Rincn, J. Bartacek, R. Borja and D. Jeiso, in Biodegradation - Engineering and Technology, ed. R. Chamy, InTech, 2013.

156 V. Klassen, O. Blifernez-Klassen, D. Wibberg, A. Winkler, J. Kalinowski, C. Posten and O. Kruse, Biotechnol. Biofuels, 2017, 10, 186.

157 R. Rajagopal, D. I. Massé and G. Singh, Bioresour. Technol., 2013, 143, 632-641.

158 L. Lombardi, B. Mendecka and S. Fabrizi, Energies, 2020, 13, 4292.

159 J. C. Quinn, A. Hanif, S. Sharvelle and T. H. Bradley, Bioresour. Technol., 2014, 171, 37-43. 